\title{
Cetylpyridinium Bromide/Polyvinyl Chloride for Substantially Efficient Capture of Rare Earth Elements from Chloride Solution
}

\author{
Eman M. Allam ${ }^{1, *}$, Taysser A. Lashen ${ }^{1}$, Saeyda A. Abou El-Enein ${ }^{2}$, Mohamed A. Hassanin ${ }^{1}$, Ahmed K. Sakr ${ }^{1} \mathbb{D}_{\text {, }}$ \\ Mohamed Y. Hanfi ${ }^{1,3}$, M. I. Sayyed ${ }^{4,5}$ (D) Jamelah S. Al-Otaibi ${ }^{6}$ and Mohamed F. Cheira ${ }^{1, * D}$ \\ 1 Nuclear Materials Authority, El Maadi, Cairo P.O. Box 530, Egypt; ah841873@ucf.edu (T.A.L.); \\ mmsh236@yahoo.com (M.A.H.); akhchemist@gmail.com (A.K.S.); mokhamed.khanfi@urfu.ru (M.Y.H.) \\ 2 Department of Chemistry, Faculty of Science, Menoufia University, Shebin El-Kom 32511, Egypt; \\ dr.saeyda_elenein@yahoo.com \\ 3 Institute of Physics and Technology, Ural Federal University, St. Mira, 19, 620002 Yekaterinburg, Russia \\ 4 Department of Nuclear Medicine Research, Institute for Research and Medical Consultations (IRMC), \\ Imam Abdulrahman Bin Faisal University (IAU), P.O. Box 1982, Dammam 31441, Saudi Arabia; \\ mabualssayed@ut.edu.sa \\ 5 Department of Physics, Faculty of Science, Isra University, Amman 11622, Jordan \\ 6 Department of Chemistry, College of Science, Princess Nourah Bint Abdulrahman University, P.O. Box 84428, \\ Riyadh 11671, Saudi Arabia; jsalotabi@pnu.edu.sa \\ * Correspondence: dr_e.allam@yahoo.com (E.M.A.); mf.farid2008@yahoo.com (M.F.C.)
}

\section{check for}

updates

Citation: Allam, E.M.; Lashen, T.A.; Abou El-Enein, S.A.; Hassanin, M.A.; Sakr, A.K.; Hanfi, M.Y.; Sayyed, M.I.; Al-Otaibi, J.S.; Cheira, M.F.

Cetylpyridinium Bromide/Polyvinyl Chloride for Substantially Efficient

Capture of Rare Earth Elements from Chloride Solution. Polymers 2022, 14 , 954. https://doi.org/10.3390/ polym14050954

Academic Editor: Cristina Cazan

Received: 20 January 2022

Accepted: 24 February 2022

Published: 27 February 2022

Publisher's Note: MDPI stays neutral with regard to jurisdictional claims in published maps and institutional affiliations.

Copyright: (C) 2022 by the authors. Licensee MDPI, Basel, Switzerland. This article is an open access article distributed under the terms and conditions of the Creative Commons Attribution (CC BY) license (https:// creativecommons.org/licenses/by/ $4.0 /)$.

\begin{abstract}
A new sorbent cetylpyridinium bromide/polyvinylchloride (CPB/PVC) was prepared and tested to extract rare earth elements (REEs) from their chloride solutions. It was identified by FTIR, TGA, SEM, EDX, and XRD. The impact of various factors such as $\mathrm{pH}, \mathrm{RE}$ ion initial concentration, contacting time, and dose amount via sorption process was inspected. The optimum $\mathrm{pH}$ was 6.0, and the equilibrium contact time was reached at $60 \mathrm{~min}$ at $25^{\circ} \mathrm{C}$. The prepared adsorbent (CPB/PVC) uptake capacity was $182.6 \mathrm{mg} / \mathrm{g}$. The adsorption of RE ions onto the CPB/PVC sorbent was found to fit the Langmuir isotherm as well as pseudo-second-order models well. In addition, the thermodynamic parameters of RE ion sorption were found to be exothermic and spontaneous. The desorption of RE ions from the loaded CPB/PVC sorbent was investigated. It was observed that the optimum desorption was achieved at $1.0 \mathrm{M} \mathrm{HCl}$ for 60 min contact time at ambient room temperature and a 1:60 solid: liquid phase ratio (S:L). As a result, the prepared CPB/PVC sorbent was recognized as a competitor sorbent for REEs.
\end{abstract}

Keywords: rare earth ions; cetylpyridinium bromide; polyvinylchloride; sorption; desorption

\section{Introduction}

The rare earth elements (REEs) are the lanthanides series, scandium, and yttrium, except for promethium, all of which occur in nature. The REEs are found fixed in their minerals and act as the same chemical entity [1]. Rare earth elements are not found as individual compounds, but the mineral usually contains all the REEs with some enrichment of them by the cerium group or yttrium group. However, most REEs occur, in principle, only three ore minerals, namely, monazite, bastnasite (as a resource of the cerium group), and xenotime (as a source of the yttrium group) [2].

REEs have evolved into an essential aspect of current life in a wide range of products; thus, their recovery procedures now hold great consideration. The recovery of REEs is a complicated process that involves ore mining, mineral dressing, chemical upgrading, and refining. The crucial refining steps must result in the possible extraction of the REEs existing in the ore with the lowest possible cost [3-6].

Currently, there are great efforts to find innovative materials and technologies to extract RE ions from their solutions. Impregnation techniques have been developed as a substitute for ion exchange or solvent extraction as it overcomes the drawbacks of these 
techniques. These techniques depend on the alteration of solid support to extract the desired ions of their complex solutions. Two approaches were exploited for construction; the first method depends on the physical modification of solid support using a suitable reagent, and the second method comprises a chelating ligand toward the solid phase support. A variety of extraction techniques were evolved for selective extraction of RE ions using various solid-phase supports such as benzophenone, activated carbon, $\mathrm{SiO}_{2}$, titanium oxide, naphthalene, resins, clay, etc. [7-10].

REEs are recovered from ore materials, requiring some hydrometallurgical functions. Great efforts have been concentrated upon pristine materials to separate REEs. Impregnated resins were produced by altering solid supports for the separation of ions from complex matrices. Two methods were utilized to organize the solid set; one based on the physical modification of a proper solvent at the solid support. The second process implicates attaching the chelating complex to a support material. For individual REE extraction, various solid-extraction approaches have been conceived using solid supports of distinct types such as activated carbon, clays, $\mathrm{SiO}_{2}$, polymeric resins, titanium oxide, and naphthalene [10-21]. The extraction of lanthanides from positively acidic wastes has been proposed using a resin, which was developed by a dihexyl succinamic/chloromethylated polymer [22].

Nonionic Amberlite XAD-16 polymeric crosslinked with undiluted tributyl phosphate (TBP) was used to uptake $\mathrm{Ce}^{4+}$ ions from nitrate solution [23]. Mono aza dibenzo crown ether/Amberlite XAD-4 was employed for the removal of $\mathrm{Sm}^{3+}, \mathrm{La}^{3+}$, and $\mathrm{Nd}^{3+}$ [24]. A nonionic Amberlite XAD-4 polymeric anchored by vanillinsemicarbazone was used to separatee $\mathrm{Ce}^{3+}$ and $\mathrm{La}^{3+}$ [25]. Furthermore, $\mathrm{La}^{3+}$, along with $\mathrm{Ce}^{3+}$ ions, were extracted with ethylhexyl phosphonic acid mono-ethylhexyl ester covered by polyvinyl alcohol and linked through divinyl sulfone or glutaraldehyde [26].

Rare earth ion extraction was also investigated using hexyl-ethyl-octyl-isopropylphosp honic acid/resin from $\mathrm{HCl}$ solutions [27]. Bis(2-ethylhexyl) phosphoric acid/polyethersulfo ne polymer was employed to separate rare earth ions from chloride, perchlorate, and sulfate media [28]. Moreover, bis(ethylhexyl)phosphoric acid/resin was utilized to separate $\mathrm{Zn}$, $\mathrm{Ca}, \mathrm{Pr}, \mathrm{Ce}, \mathrm{Nd}, \mathrm{Fe}, \mathrm{Sm}$, and $\mathrm{Al}$ [29]. The rare earth ion separation was initiated by designing a polyethersulfone composite via phase inversion technique [30]. Extraction of $\mathrm{La}_{2} \mathrm{O}_{3}$ from monazite was performed in four steps: (a) extraction of lanthanum hydroxide using $\mathrm{NaOH}$; (b) digestion with $\mathrm{HNO}_{3}$; (c) precipitation with $\mathrm{NH}_{4} \mathrm{OH}$; and (d) calcination to $\mathrm{La}_{2} \mathrm{O}_{3}$ [31].

The recovery of REEs was examined using silica gel modified with diglycolamic acid [32]. A strong cation exchange resin (Amberlite 1R-120) was used for the adsorption of RE(III) ions from a standard and obtained leach liquor solution from phosphate ore by applying optimum leaching conditions; the optimum conditions for the loading of RE ions onto Amberlite 1R-120 were determined in a batch system [33]. Treated clay impregnated with m-aminophenol and amino-hydroxypyrazole was utilized to capture REEs [10].

In this study, polyvinyl chloride (PVC) was impregnated by cetylpyridinium bromide (CPB) to increase its sorption capacity. The physicochemical structure and properties of PVC and CPB/PVC sorbents were first characterized by SEM, XRD, EDX, FTIR, and TGA. Second, the REE sorption properties of these two materials were compared by studying the parameters that affected the sorption process such as $\mathrm{pH}$, initial REE concentration, PVC and $\mathrm{CPB} / \mathrm{PVC}$ dosage, and contact time. The uptake kinetics and sorption isotherms were also deliberated. Finally, the regeneration and recycling of the two sorbents were examined.

\section{Materials and Methods}

\subsection{Materials}

The REE standard stock solution was prepared by dissolving a mixture of $0.2649 \mathrm{~g}$ of $\mathrm{LaCl}_{3}, 0.3989 \mathrm{~g}$ of $\mathrm{CeCl}_{3} \cdot 7 \mathrm{H}_{2} \mathrm{O}, 0.2632 \mathrm{~g}$ of $\mathrm{PrCl}_{3}, 0.2606 \mathrm{~g}$ of $\mathrm{NdCl}_{3}, 0.3639 \mathrm{~g}$ of $\mathrm{SmCl}_{3} \cdot 6 \mathrm{H}_{2} \mathrm{O}$, and $0.3294 \mathrm{~g}$ of $\mathrm{YCl}_{3}$ in $900 \mathrm{~mL}$ deionized water acidified by $15.0 \mathrm{~mL}$ concentrated $\mathrm{HCl}$ (36.5\%) to prevent hydrolysis. These salts were supplied through B.D.H. Chem., Poole, England. The salts weights were equivalent to $150 \mathrm{mg} / \mathrm{L}$ for each individual $\mathrm{La}^{3+}, \mathrm{Ce}^{3+}$, 
$\mathrm{Pr}^{3+}, \mathrm{Nd}^{3+}, \mathrm{Sm}^{3+}$, or $\mathrm{Y}^{3+}$ ions. However, $900 \mathrm{mg}$ of total $\mathrm{RE}$ ions were dissolved in $900 \mathrm{~mL}$ distilled water. Hence, RE ion concentration was equivalent to $1 \mathrm{mg} / \mathrm{mL}(1000 \mu \mathrm{g} / \mathrm{mL}=$ $1000 \mathrm{mg} / \mathrm{L})$. Polyvinyl chloride $\left(\left(\mathrm{CH}_{2} \mathrm{CHCl}\right)_{\mathrm{n}}\right)$ was supplied by Sigma-Aldrich, St. Louis, MO, USA, it has a molecular weight $(\approx 48,000 \mathrm{~g} / \mathrm{mol})$ and its molecular weight of the repeat unit was $62.5 \mathrm{~g} / \mathrm{mol}$. Additionally, cetylpyridinium bromide hydrate (CPB), arsenazo III, $\mathrm{HCl}$, and $\mathrm{NaOH}$ were gained from Sigma-Aldrich.

A UV-Visible spectrophotometer (UV-2700i, Shimadzu, Kyoto, Japan) with $1.0 \mathrm{~cm}$ quartz cell covering the range of 200-1100 nm was used for the spectrophotometric analysis of total REEs by arsenazo III (indicator) at $650 \mathrm{~nm}$ as a control analysis for the adsorption process [34]. All $\mathrm{pH}$ measurements were carried out using a digital $\mathrm{pH}$-meter, Inolab $\mathrm{pH}$, Xylem Inc., Rye Brook, NY, USA, level 1.0, with an error of \pm 0.01 at ambient laboratory temperature. An inductively coupled plasma-optical emission spectrometer ICP-OES (Agilent 5800, Santa Clara, CA, USA) instrument was employed to measure the concentration of RE ions.

The sorbent's crystal structure was examined by XRD (Empyrean, Malvern Panalytical, Almelo, The Netherlands). The sorbent's morphology was scrutinized via scanning electron microscopy with energy dispersive X-ray analysis (SEM-EDX, Philips XL 30, Eindhoven, The Netherlands). The specific surface area, size of substances, and pore volume were measured using nitrogen sorption at $77 \mathrm{~K}$ (Nova 2000 series, Quantachrone Corporation, Boynton Beach, FL, USA). The functional groups of the studied sorbents were evaluated by Fourier transform infrared (FTIR) spectroscopy (IR Prestige-21, Shimadzu, Kyoto, Japan) using IR resolution software via the $\mathrm{KBr}$ method. The spectra were recorded in the range of $400-4000 \mathrm{~cm}^{-1}, 4.0 \mathrm{~cm}^{-1}$ resolution, and 50 scans. A thermogravimetric analyzer (TGA 8000, Perkin Elmer, Waltham, MA, USA) was utilized to detect the thermal stability at $10{ }^{\circ} \mathrm{C} / \mathrm{min}$ and temperature range of $25-900^{\circ} \mathrm{C}$.

\subsection{Preparation of Cetylpyridinium Bromide Hydrate/Polyvinyl Chloride}

The dry method was utilized for the modification process. The impregnation conditions were optimized through a series of experiments. A total of $1.0 \mathrm{~g}$ cetylpyridinium bromide hydrate was dissolved in $25.0 \mathrm{~mL}$ acetone, and then it was added dropwise into a suspended solution of $10.0 \mathrm{~g}$ of polyvinyl chloride in $50.0 \mathrm{~mL}$ of acetone with stirring for $2.0 \mathrm{~h}$ at $25{ }^{\circ} \mathrm{C}$ until complete homogenization and dryness. The modified polyvinyl chloride with cetylpyridinium bromide hydrate was physically formed and dried at $60{ }^{\circ} \mathrm{C}$ (Scheme 1).

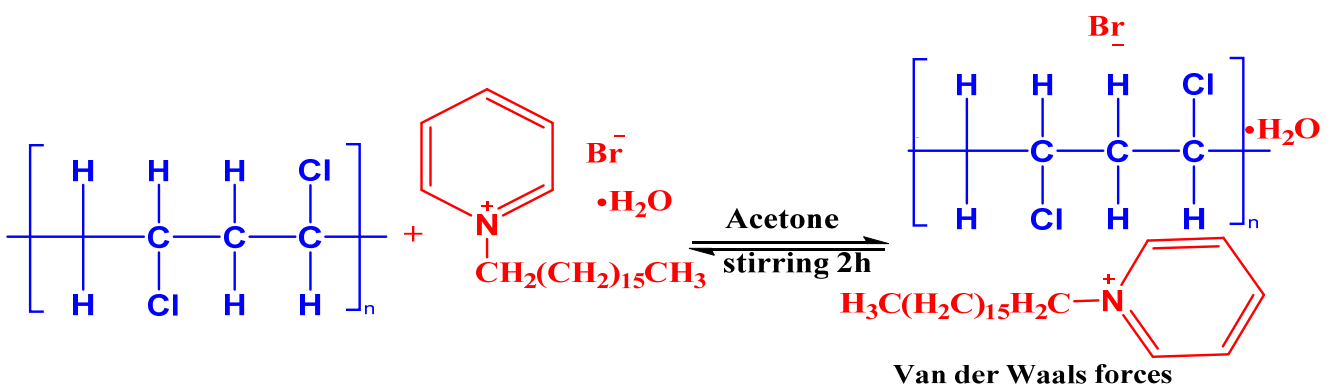

Scheme 1. The suggested mechanism of cetylpyridinium bromide hydrate/PVC.

\subsection{REE Sorption Studies}

Many experiments were carried out to identify the applicable parameters affecting the REE extraction from the synthetic solution on both PVC and CPB/PVC adsorbents. The studied factors were solution $\mathrm{pH}$, REE concentration, sorbent dosage, time of sorption, and temperature.

A series of experiments was studied by a different concentration of the REE synthetic solution with constant volume to fix the optimum parameters. The effect of $\mathrm{pH}$ on the sorption of REEs was examined with a $\mathrm{pH}$ value from 1.0 to 7.0. The $\mathrm{pH}$ in all experiments was 
adjusted by $0.2 \mathrm{M} \mathrm{HCl}$ as well as a $0.2 \mathrm{M} \mathrm{NaOH}$ solution. In contrast, the effects of sorbent quantity (10 to $90 \mathrm{mg}$ ) and contact time (5-120 min) were investigated. Moreover, different initial concentrations of rare earth ions were designated in 25-400 mg/L. The sorption uptake $\mathrm{q}_{\mathrm{e}}(\mathrm{mg} / \mathrm{g})$, efficiency $(\mathrm{E}, \%)$, and distribution parameter $\left(\mathrm{K}_{\mathrm{d}}\right)$ were generated by the subsequent equations [35-38].

$$
\begin{gathered}
\mathrm{q}_{\mathrm{e}}=\frac{\left(\mathrm{C}_{\mathrm{o}}-\mathrm{C}_{\mathrm{e}}\right) \mathrm{V}}{\mathrm{m}} \\
\mathrm{E}, \%=\left(\frac{\mathrm{C}_{\mathrm{o}}-\mathrm{C}_{\mathrm{e}}}{\mathrm{C}_{\mathrm{o}}}\right) \times 100 \\
\mathrm{~K}_{\mathrm{d}}=\left(\frac{\mathrm{C}_{\mathrm{o}}-\mathrm{C}_{\mathrm{e}}}{\mathrm{C}_{\mathrm{e}}}\right) \times \frac{\mathrm{V}}{\mathrm{m}}
\end{gathered}
$$

$\mathrm{C}_{\mathrm{e}}$ and $\mathrm{C}_{\mathrm{o}}(\mathrm{mg} / \mathrm{L})$ are defined as the equilibrium and initial REE concentration, $\mathrm{V}(\mathrm{L})$ is solution volume, and $\mathrm{m}(\mathrm{g})$ represents the sorbent weight.

\subsection{Desorption Studies}

The rare earth ions loaded on PVC or CPB/PVC were exposed for stripping process to study the desorption aspects of the rare earth ions. The desorption methods were conducted on either $0.5 \mathrm{~g}$ of REE/PVC or REE/CPB/PVC using a $25.0 \mathrm{~mL}$ of various concentrations of $\mathrm{HCl}, \mathrm{NaCl}, \mathrm{H}_{2} \mathrm{SO}_{4}$, and $\mathrm{HNO}_{3}$ in the range from 0.1 to $3.0 \mathrm{M}$ for a $60 \mathrm{~min}$ desorption time and then separated by filtration; the filtrate was analyzed to detect the concentration of eluting RE ions. The desorption parameters (the eluting type, the concentration of eluent, desorption time, and temperature) were investigated. After the REE-loaded adsorbent with treated with the eluting agent, it was rinsed carefully with deionized water to prepare it for recycling.

\section{Results and Discussion}

\subsection{Depiction of Materials}

\subsubsection{XRD Investigation}

The XRD spectra of PVC, CPB/PVC, REE/PVC, and REE/CPB/PVC are shown in Figure 1. The data in Figure 1a of the PVC show that the polymer exhibited two peaks at $2 \theta$ angles of $18.0^{\circ}$ and $25.0^{\circ}$ due to its amorphous nature [39]. However, the small peak at $2 \theta=39.5^{\circ}$ indicated the polymer semi-crystalline structure [40]. The other peaks were combined into one peak at $2 \theta=24.0^{\circ}$ for the CPB/PVC spectrum, and the peak at $2 \theta=39.5^{\circ}$ disappeared (Figure 1c). Consequently, it can be concluded that CPB was distributed into PVC to compose CPB/PVC.

The XRD of the REE/PVC spectrum, in Figure $1 \mathrm{~b}$ was slightly broadened and shifted to $19.0^{\circ}$ and $24.0^{\circ}$. Furthermore, the peak at $2 \theta=39.5^{\circ}$ in Figure $1 \mathrm{a}$ also disappeared due to the PVC polymer structure being amorphous. The data quantified that the rare earth ions were sorbed on the PVC surface. The XRD of REEs/CPB/PVC is shown in Figure 1d. From the XRD of CPB/PVC (Figure 1c), the peak position and peak shape of CPB/PVC at $2 \theta=24.0^{\circ}$ was enlarged and had a change in position to $2 \theta=26.0^{\circ}$, and new peaks were gained at $17.0^{\circ}$ and $19.0^{\circ}$ for the XRD pattern of REE/CPB/PVC in Figure $1 \mathrm{~d}$, indicating that the REEs were adsorbed on CPB/PVC. 

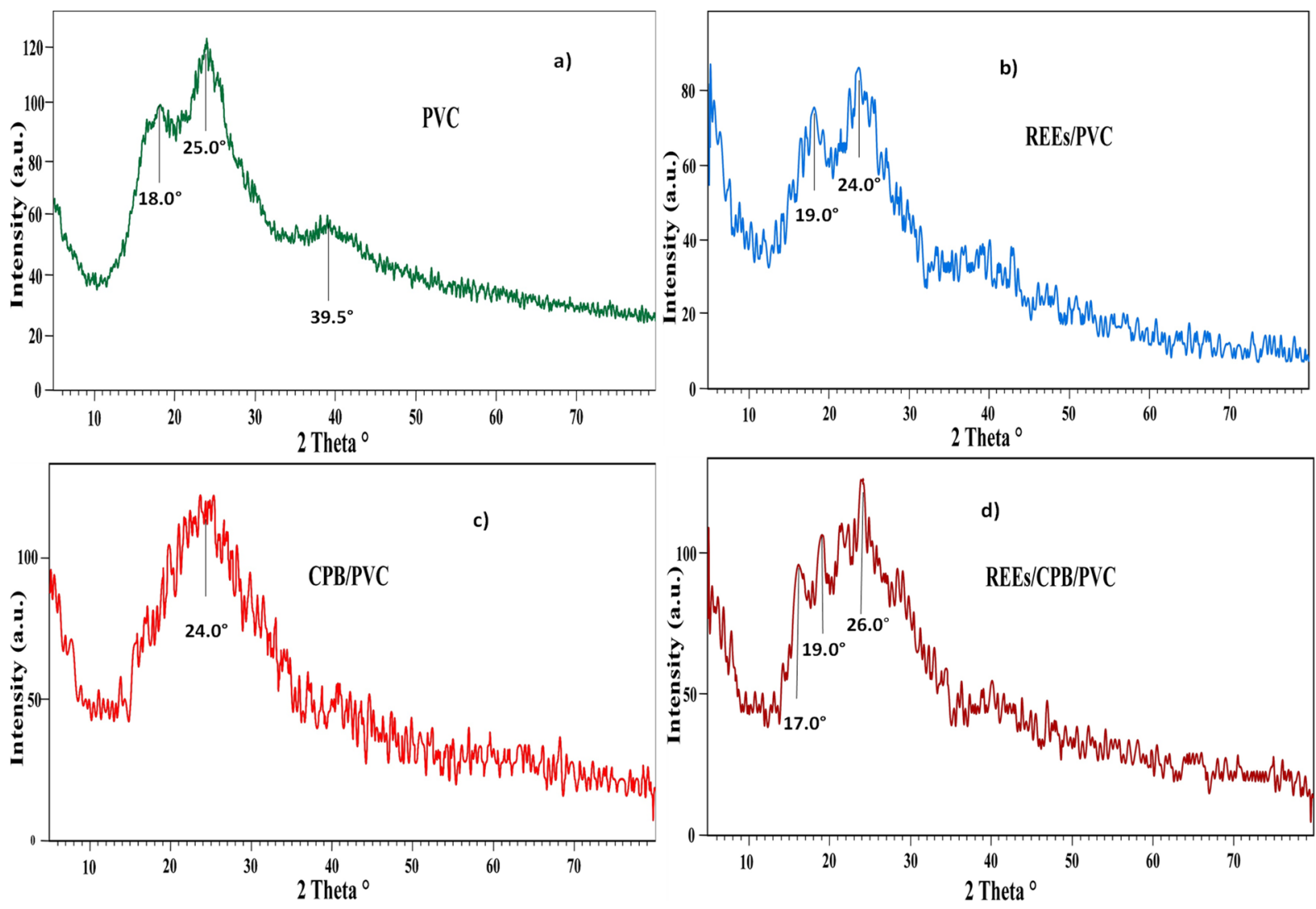

Figure 1. XRD analysis of (a) PVC, (b) REEs/PVC, (c) CPB/PVC, (d) REE/CPB/PVC.

\subsubsection{SEM-EDX Investigations}

Figure 2a illustrates that the PVC surface was approximately smooth, spotless, and had no fissures with minor drawbacks due to slight differences in the morphology of the tiny granules of PVC. At the same time, the CPB/PVC image was recognized with few aggregations with structures that seem to be a little globular and regular (Figure 2c). On the other hand, the loaded RE ions on PVC or CPB/PVC images in Figure 2b,d showed that the particles were agglomerated, and RE ions were observed as white spots on the surface of two sorbents. From the results, evident surface morphology changes in the REE/PVC or $\mathrm{REE} / \mathrm{CPB} / \mathrm{PVC}$ sorbents confirmed that the REE sorption onto the studied two sorbents was achieved.

The semi-quantitative EDX investigation of PVC along with CPB/PVC before and after REE sorption was premeditated. From the results, $\mathrm{C}$ and $\mathrm{Cl}$ bands were accessible in the PVC; furthermore, no additional bands were noticed (Figure 2e). In contrast, the $\mathrm{CPB} / \mathrm{PVC}$ contained $\mathrm{N}, \mathrm{C}, \mathrm{Cl}$, and $\mathrm{Br}$ peaks (Figure $2 \mathrm{~g}$ ). These results emphasize that the CPB/PVC was established and formed. Therefore, it can be concluded that CPB was distributed into PVC to form $\mathrm{CPB} / \mathrm{PVC}$ due to the surface electrostatic interaction. After rare earth ion sorption, discrete peaks of some rare earth ions $(\mathrm{Y}, \mathrm{La}, \mathrm{Ce}, \mathrm{Pr}, \mathrm{Nd}, \mathrm{Sm})$ were found on the two sorbents (Figure 2f,h). The REE peaks were perceived and confirmed REE sorption on PVC and CPB/PVC. 

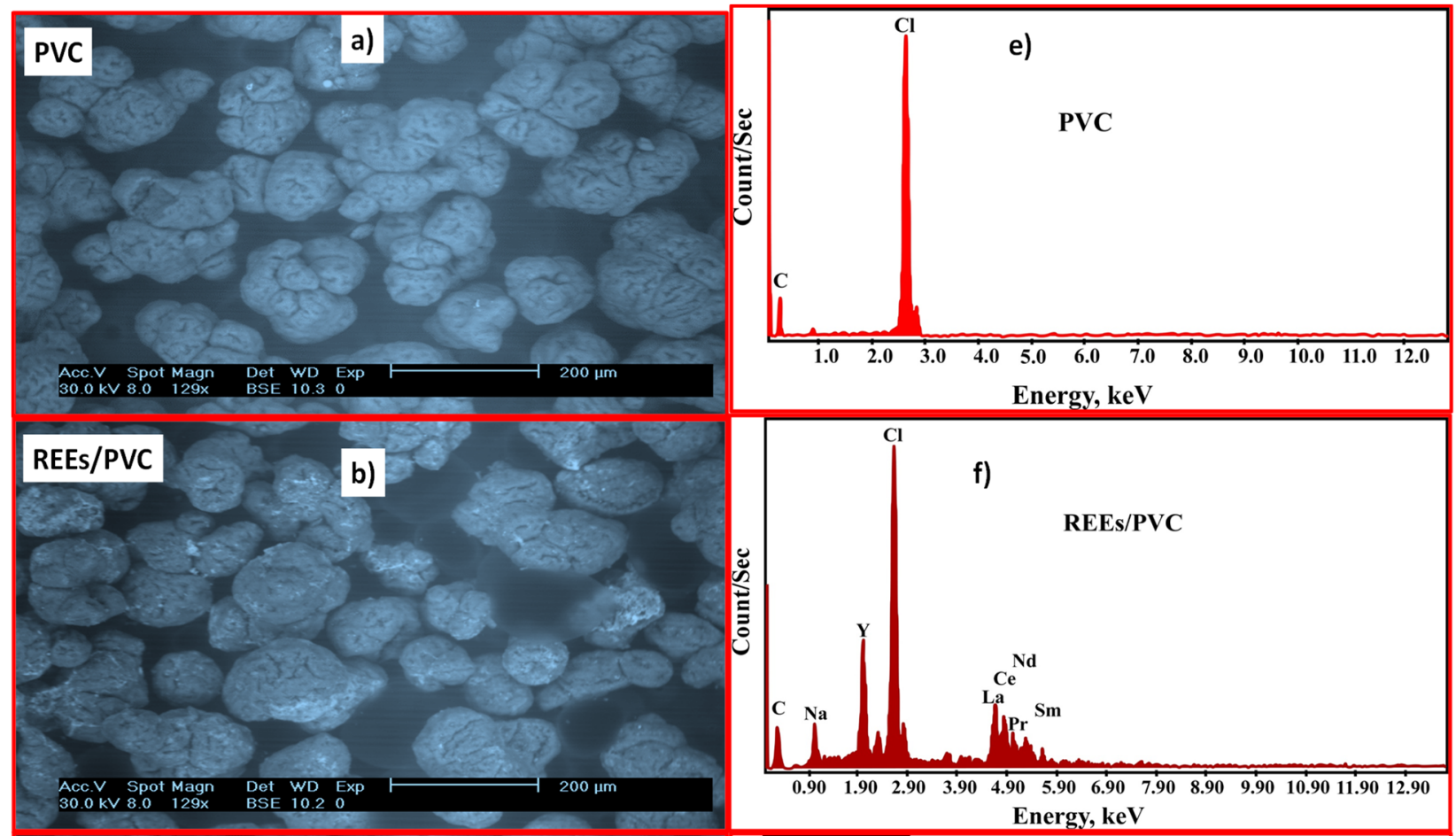

\section{CPB/PVC}
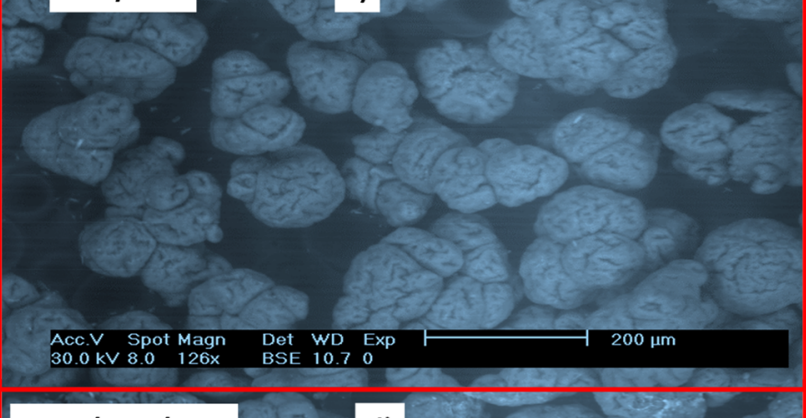

REEs/CPB/PVC

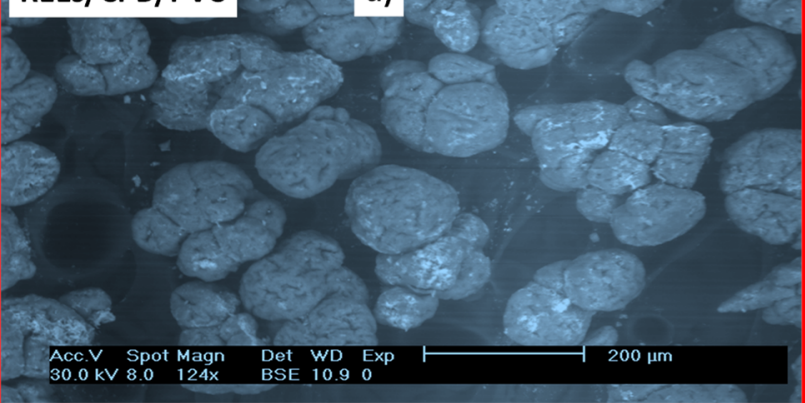

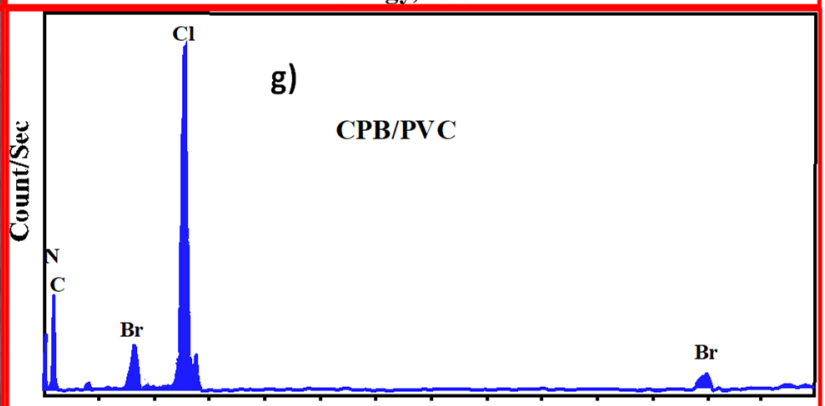

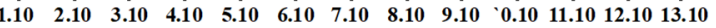
Energy, keV

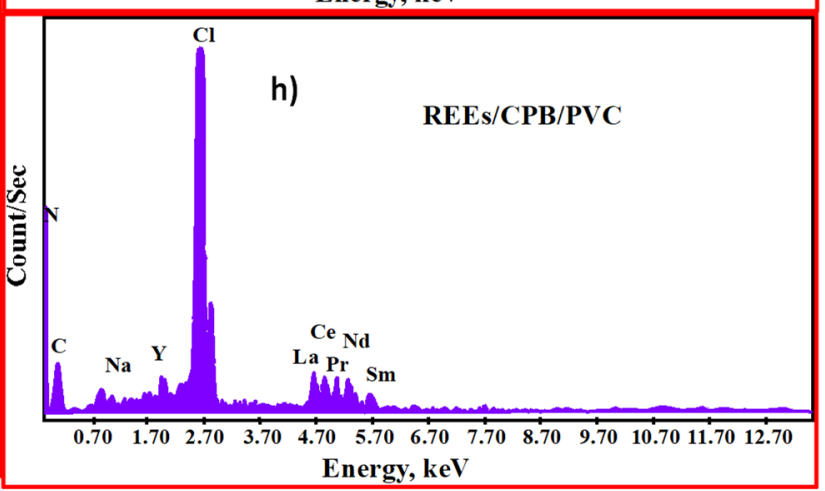

Figure 2. SEM pictures of (a) PVC, (b) REE/PVC, (c) CPB/PVC, (d) REE/CPB/PVC and EDX investigation of (e) PVC, (f) REE/PVC, (g) CPB/PVC, (h) REE/CPB/PVC.

\subsubsection{BET Surface Analysis}

The Brunner-Emmett-Teller theory (BET) was utilized to examine the surface area of either solid or porous materials. It provides crucial information about their physical structure, as the area of the solid surface of the substance influences how that solid interacts with its surroundings. During either synthesis or processing, the surface area of a material can be changed. The surface area of a particle increases when pores are created within its interior by decomposition and dissolution as well as other physical or chemical means. A 
nitrogen adsorption-desorption analyzer was used to assess the specific surface area and the studied adsorbents' pore size. The four samples were dried before analysis to $60^{\circ} \mathrm{C}$ for $2.0 \mathrm{~h}$.

Table 1 and Figure $3 a$ illustrate that PVC surface area, pore size, and volume were $94.06 \mathrm{~m}^{2} / \mathrm{g}, 1.94 \mathrm{~nm}$, and $0.091 \mathrm{cc} / \mathrm{g}$. Moreover, the CPB/PVC surface area, pore size, and volume were $68.32 \mathrm{~m}^{2} / \mathrm{g}, 2.91 \mathrm{~nm}$, and $0.099 \mathrm{cc} / \mathrm{g}$ (Figure $3 \mathrm{~b}$ ). With the addition of CPB to $\mathrm{PVC}$, the surface area of $\mathrm{CPB} / \mathrm{PVC}$ was decreased. From the result, it may be attributed that $\mathrm{CPB}$ was impregnated in PVC. After rare earth ion sorption, the surface area, pore size, and volume of the $\mathrm{PVC}$ or $\mathrm{CPB} / \mathrm{PVC}$ sorbents were decreased because rare earth ions blocked the active sites (Figure $3 c, d$ ). The attained results exposed that rare earth ions were more strongly adsorbed on the $\mathrm{CPB} / \mathrm{PVC}$ than the $\mathrm{PVC}$ due to $\mathrm{CPB} / \mathrm{PVC}$ having more active spots than PVC.

Table 1. Surface area, porosity, and pore volume of PVC and CPB/PVC previously and after rare earth ion sorption.

\begin{tabular}{cccc}
\hline Materials & $\mathbf{S}_{\mathbf{B E T}}, \mathbf{~}^{\mathbf{2}} \mathbf{g}$ & Pore Size, $\mathbf{n m}$ & Pore Volume, $\mathbf{c c} \mathbf{g}$ \\
\hline PVC & 94.06 & 1.94 & 0.091 \\
\hline $\mathrm{CPB} / \mathrm{PVC}$ & 68.32 & 2.91 & 0.099 \\
\hline $\mathrm{REE} / \mathrm{PVC}$ & 39.09 & 1.82 & 0.035 \\
\hline $\mathrm{REE} / \mathrm{CPB} / \mathrm{PVC}$ & 65.19 & 2.88 & 0.095 \\
\hline
\end{tabular}
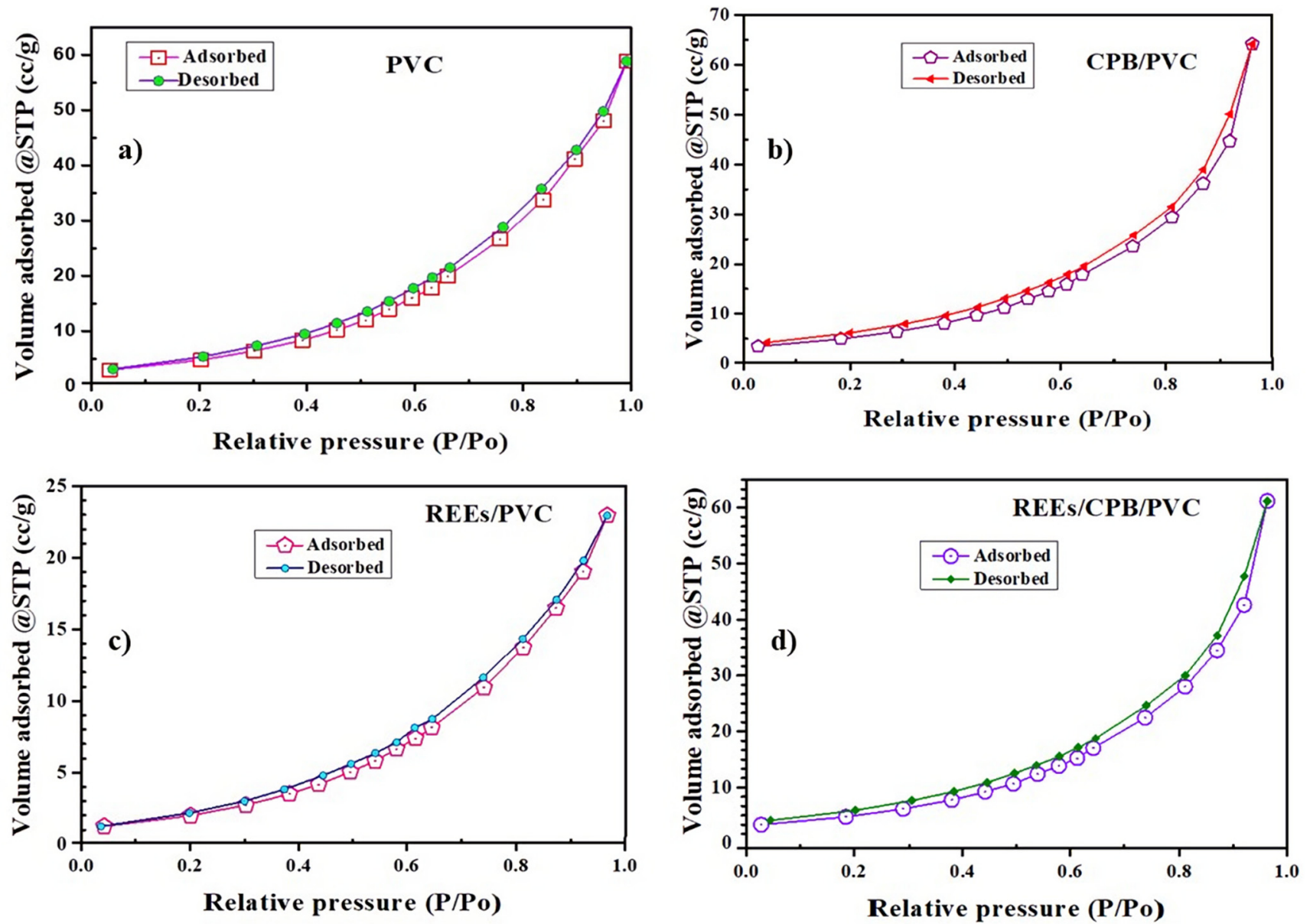

Figure 3. $\mathrm{N}_{2}$ sorption/desorption isotherm of (a) PVC, (b) CPB/PVC, (c) REE/PVC, and (d) $\mathrm{REE} / \mathrm{CPB} / \mathrm{PVC}$. 


\subsubsection{FTIR Investigation}

The functional groups attached to the surface of the materials under study were recognized by FTIR spectroscopy [41]. The PVC spectrum in Figure 4a showed that two peaks at the 606 and $682 \mathrm{~cm}^{-1}$ were related to the $\mathrm{C}-\mathrm{Cl}$ stretching mode, according to the polymer conformation structure and the locative position of the surrounding atoms according to $\mathrm{C}-\mathrm{Cl}$ bonds [42]. The peaks at $2911-2969 \mathrm{~cm}^{-1}$ matched $-\mathrm{CH}_{2}-$ and $-\mathrm{CH}$ groups. The assignments at 1250 and $1331 \mathrm{~cm}^{-1}$ indorsed $-\mathrm{CH}$ in the $-\mathrm{CHCl}$ group [43]. The intensity of the $\mathrm{C}-\mathrm{H}$ band was also improved with the impregnation with cetylpyridinium bromide hydrate. Furthermore, the intensity of all of the $\mathrm{C}-\mathrm{Cl}$ bands was increased.

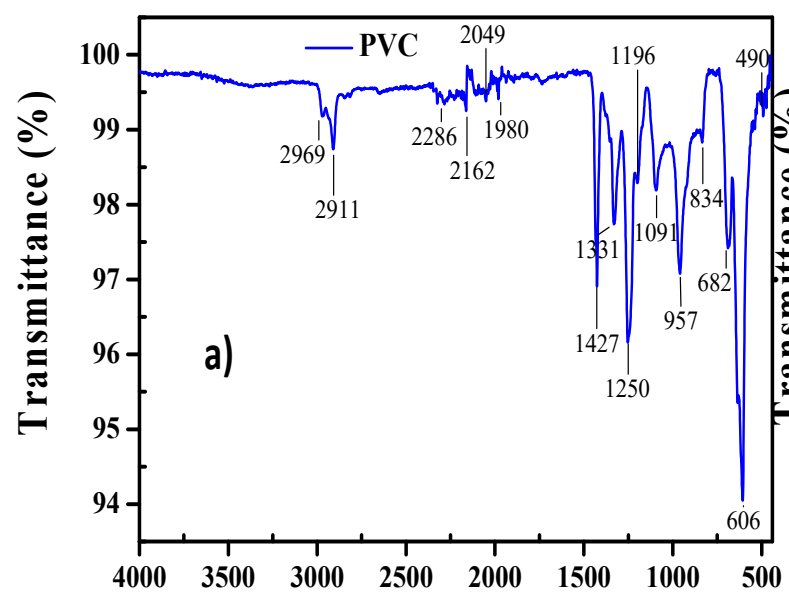

Wavenumbers $\left(\mathrm{cm}^{-1}\right)$

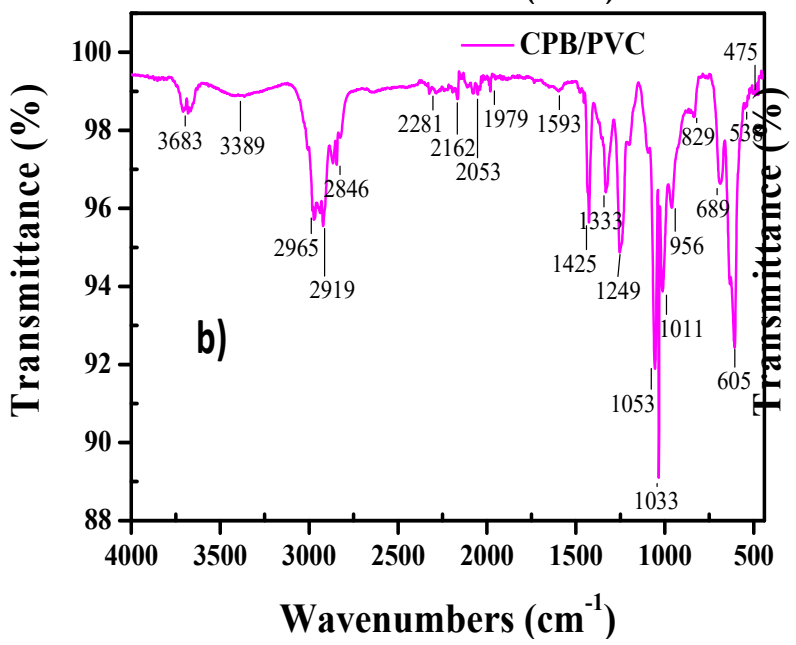

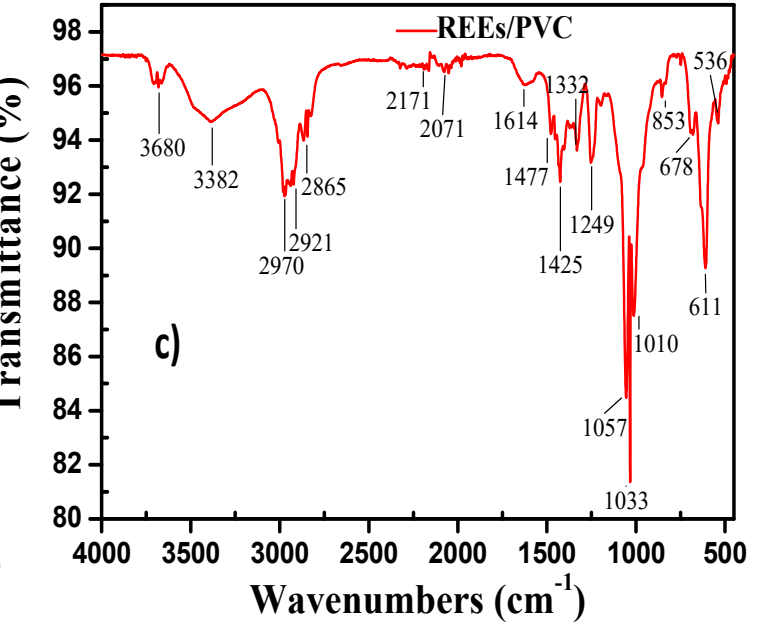

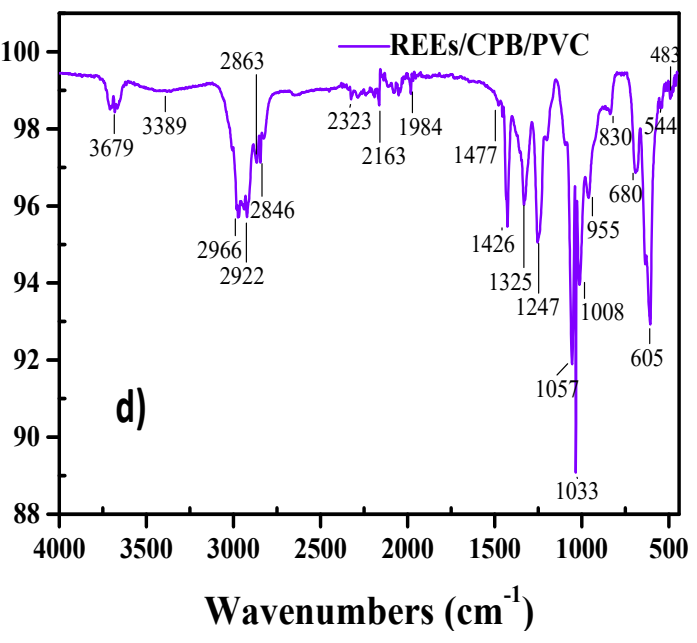

Figure 4. FTIR spectra of (a) PVC, (b) CPB/PVC, (c) REE/PVC, (d) REE/CPB/PVC.

The prepared cetylpyridinium bromide hydrate/polyvinyl chloride spectrum exhibited a band at $3389 \mathrm{~cm}^{-1}$ because of the $\mathrm{O}-\mathrm{H}$ of hydration (Figure $4 \mathrm{~b}$ ). The vibrational band at $1593 \mathrm{~cm}^{-1}$ confirmed the $\mathrm{C}=\mathrm{C}$ aromatic of the pyridinium group. The feature at $1425 \mathrm{~cm}^{-1}$ was predictable as $\mathrm{O}-\mathrm{H}$ of the distortion peak of $\mathrm{H}_{2} \mathrm{O}$. The comparatively broad features at 1250 and $1053 \mathrm{~cm}^{-1}$ indicate the $\mathrm{C}-\mathrm{N}$ group. In addition, the two features at 605 and $689 \mathrm{~cm}^{-1}$ are due to $\mathrm{C}-\mathrm{Cl}$ stretching vibration. Hence, the $\mathrm{CPB}$ was distributed into $\mathrm{PVC}$ to form $\mathrm{CPB} / \mathrm{PVC}$ because of the electrostatic interaction at the surface (van der Waals forces) due to the presence of $\mathrm{C}-\mathrm{Cl}$, imino groups, and most of the peaks in CPB/PVC were shifted $5-10 \mathrm{~cm}^{-1}$. After REE sorption (Figure 4c,d), the vibration bands of PVC or $\mathrm{CPB} / \mathrm{PVC}$ were reduced and shifted slightly to $3-11 \mathrm{~cm}^{-1}$, which could be due to the sorption of rare earth ions on the surface sorbents [44]. 


\subsubsection{Thermal Analysis}

Thermogravimetric analysis (TGA) is a thermal analysis method for determining changes in both chemical and physical characteristics of the samples. TGA measurements are typically made as a function of temperature rise with a constant heating rate, or as a function of time with mass loss and a constant temperature. TGA measurements are typically made as a function of temperature rise with a constant heating rate, or as a function of time with mass loss with constant temperature. Physical phenomena such as second-order phase transitions, desorption, vaporization, and others can be considered using the TGA. In addition, chemical phenomena such as dehydration and decomposition can be detected. The TGA can easily determine the mass gain or loss of samples due to decomposition, loss of volatile compounds, oxidation, and degradation. Additionally, standardized TGA testing procedures can be used to determine the samples' thermal stability in terms of their resistance to thermal decomposition or degradation [45].

The TGA thermograms of PVC, CBP/PVC, REE/PVC, and REE/CBP/PVC are shown in Figure 5. The TGA curve of the PVC had two weight-loss steps with reference to the two thermal degradation steps that could be discerned in the TGA curve (Figure 5a). The first weight loss step occurred in the range of $220-332{ }^{\circ} \mathrm{C}$ and was related to removing the $\mathrm{HCl}$ consecutive reaction and forming a conjugated polyene structure. The second step appeared within the range of $445-535^{\circ} \mathrm{C}$ due to the thermal degradation of the PVC carbon chain, which yields flammable volatiles [46,47].
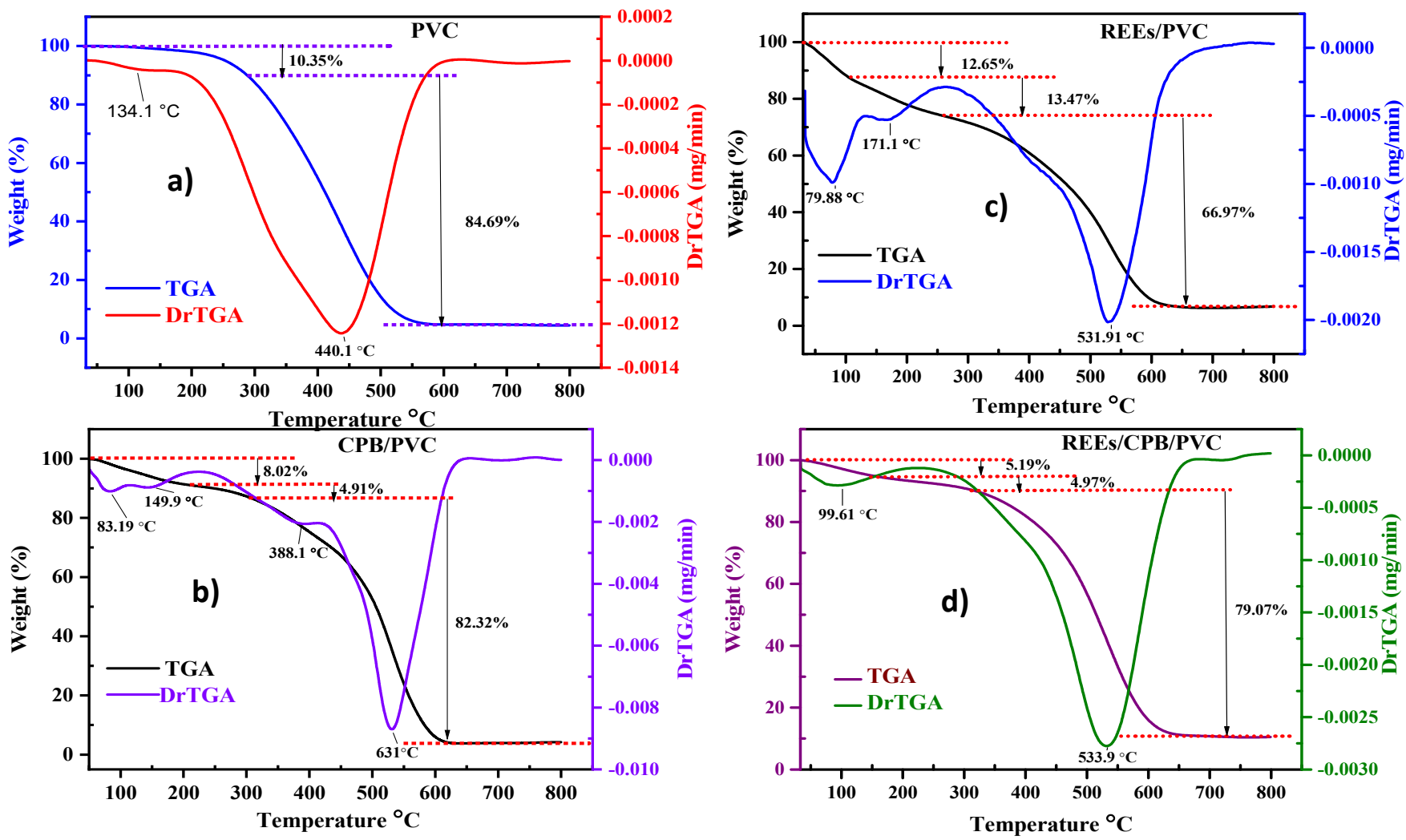

Figure 5. TGA analysis of (a) PVC, (b) CPB/PVC, (c) REEs/PVC, (d) REEs/CPB/PVC.

The thermal stabilities of CPB/PVC and REE/CBP/PVC are also shown in Figure 5b,d, which had three weight loss steps. The first step that appeared at $115^{\circ} \mathrm{C}$ was because of the loss of hydration $\mathrm{H}_{2} \mathrm{O}$. The second step occurred at $255-345^{\circ} \mathrm{C}$ due to eliminating $\mathrm{HCl}$, $\mathrm{HBr}$, and $\mathrm{NH}_{3}$ of thee $\mathrm{CPB} / \mathrm{PVC}$ sorbent. The third step was within a $350-650{ }^{\circ} \mathrm{C}$ range due to the thermal degradation of the carbon chains, which generated ignitable volatiles. In contrast, the TGA of REE/PVC exposed three weight loss stages in Figure 5c. The first stage seemed at $110{ }^{\circ} \mathrm{C}$ was due to the loss of $\mathrm{H}_{2} \mathrm{O}$ related to REEs. The second stage 
occurred at $250{ }^{\circ} \mathrm{C}$ due to the removal $\mathrm{HCl}$ from the PVC sorbent. The third stage was within the $350-600{ }^{\circ} \mathrm{C}$ range because of the thermal decomposition of the carbon chains, which resulted in the production of flammable volatiles.

The remaining residues of PVC and CPB/PVC were 4.96 and $4.75 \%$, respectively. Moreover, the residues of REE/PVC and REE/CBP/PVC were 6.91 and $10.77 \%$, respectively. Hence, the residues of REE/PVC and REE/CBP/PVC were higher than the PVC and $\mathrm{CBP} / \mathrm{PVC}$ due to the sorption and existence of REEs on the surface of the studied sorbents.

\subsection{REE Sorption Studies}

Batch techniques were executed to investigate the REE sorption on PVC or CPB/PVC as the sorbents from the RE chloride synthetic solution. These were conducted by contacting a mass of PVC or CPB/PVC with a fixed volume $(50.0 \mathrm{~mL})$ of RE ion solution. Several experiments on REE sorption efficiency were practically conducted to optimize the $\mathrm{pH}$, sorbent amount, initial RE ion conc., time of contact, and temperature.

\subsubsection{Effect of Solution $\mathrm{pH}$}

Numerous experiments were carried out with $\mathrm{pH}$ values from 1.0 to 7.0. In the meantime, the other procedure parameters were remained stable at a $50.0 \mathrm{~mL}$ solution of $200 \mathrm{mg} / \mathrm{L}$ REE, $50 \mathrm{mg}$ PVC, or CPB/PVC dose for $30 \mathrm{~min}$ at ambient temperature. The gained data from Figure 6a showed that the REE sorption efficiencies were gradually increased from 7.64 and $40.1 \%$ to 29.6 and $85.2 \%$ for PVC and CPB/PVC, respectively, with an increase in the $\mathrm{pH}$ beyond 6.0. However, REE sorption efficiencies were decreased to $24.5 \%$ for $\mathrm{PVC}$ and $77.18 \%$ for $\mathrm{CPB} / \mathrm{PVC}$ by increasing the $\mathrm{pH}$ from 6.0 to 7.0 values. Accordingly, a $\mathrm{pH}$ of $5.5-6.0$ was determined as the optimal $\mathrm{pH}$ value to conduct the succeeding rare earth ion sorption experiments.
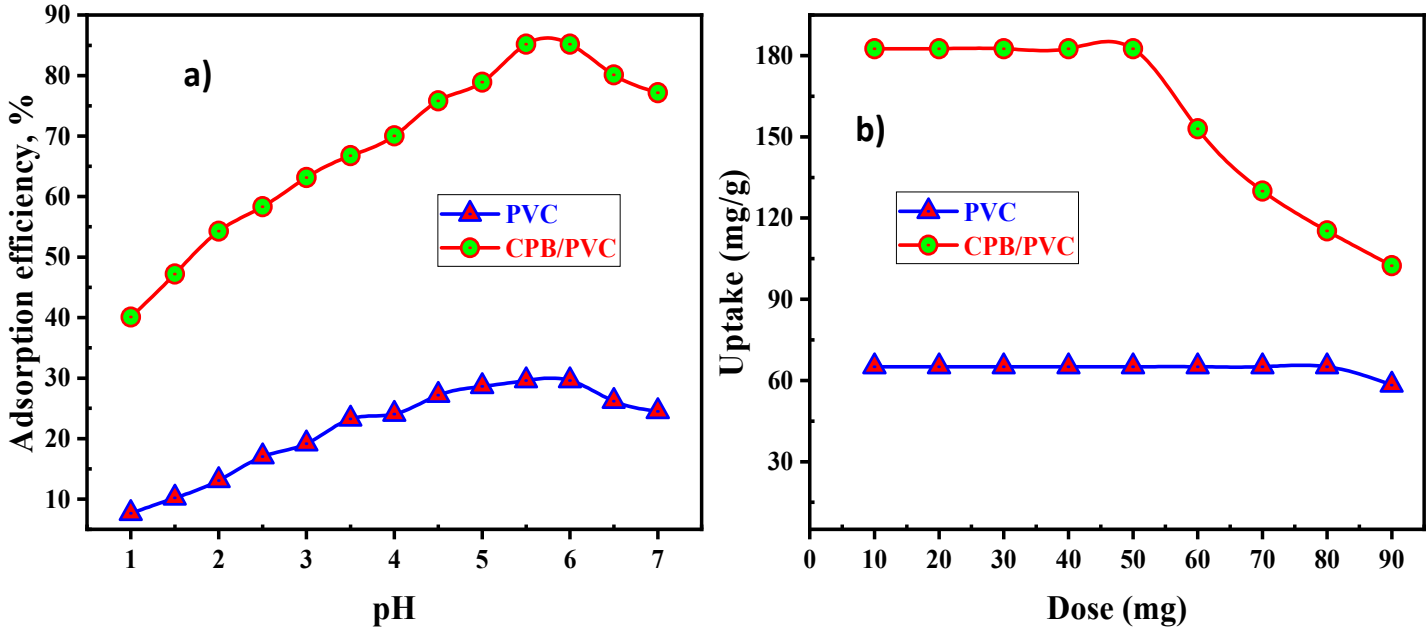

Figure 6. Effect of (a) $\mathrm{pH}$ and (b) sorbent dose on the REE sorption.

\subsubsection{Effect of Sorbent Dose}

The effect of sorbent dosage on rare earth ion sorption uptake was studied. The obtained results in Figure $6 \mathrm{~b}$ revealed that the uptakes of RE ions decreased from 65.12 and $182.6 \mathrm{mg} / \mathrm{g}$ to 58.33 and $102.44 \mathrm{mg} / \mathrm{g}$ with an increase in the dosage of sorbent material from 10 to $90 \mathrm{mg}$ for PVC and CPB/PVC, respectively. Due to an increase in the surface area, more ion exchange sites exist for ion exchange procedures at a higher dose. Thus, the $50 \mathrm{mg}$ dose was considered as a choice of sorbent dose in the subsequent experiments.

\subsubsection{Effect of Contact Time}

The influence of agitation time on the RE ion sorption on either PVC or CPB/ PVC sorbents was studied from 5-120 min, although the other sorption factors were kept 
constant. As observed in Figure 7a, the sorption efficiency of REEs was increased gradually as the sorption time increased until it achieved equilibrium at $60 \mathrm{~min}$, where its uptake was $65.12 \mathrm{mg} / \mathrm{g}$ for PVC and remained constant up to $120 \mathrm{~min}$. The sorption uptake of RE ions gradually increased from 49.25 to $182.6 \mathrm{mg} / \mathrm{g}$ after $60 \mathrm{~min}$ using CPB/PVC, and then equilibrium was achieved.
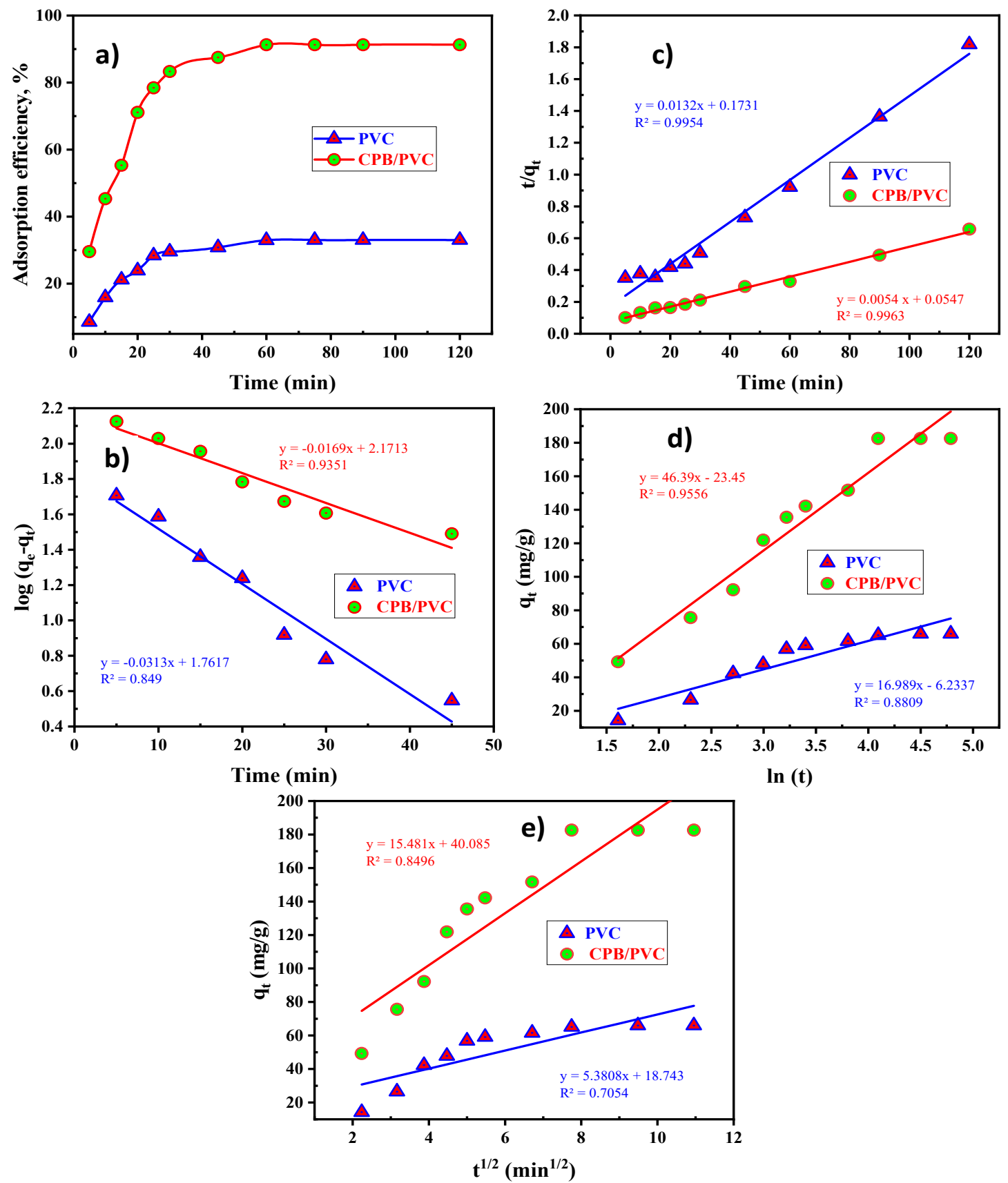

Figure 7. (a) Effect of contact time, (b) Pseudo-first-order, (c) Pseudo-second-order, (d) Elovich, (e) Intra-particle diffusion models of REE sorption on PVC and CPB/PVC. 
Kinetic Characteristics

Different kinetic models were performed for experiential data to assume the RE ion sorption kinetics on PVC or CPB/PVC. The equation of the pseudo-first-order kinetic model was expressed as [48-51]:

$$
\log \left(q_{e}-q_{t}\right)=\log q_{e}-\left(\frac{k_{1} t}{2.303}\right)
$$

Both $\mathrm{q}_{\mathrm{e}}$ and $\mathrm{q}_{\mathrm{t}}(\mathrm{mg} / \mathrm{g})$ are defined as the adsorbed amount of RE ions at equilibrium and at time $\mathrm{t}(\mathrm{min})$, and $\mathrm{k}_{1}\left(\mathrm{~min}^{-1}\right)$ represents the pseudo-first-order rate constant. The results obtained from Figure $7 \mathrm{~b}$ clarified that the $\mathrm{R}^{2}$ and $\mathrm{q}_{\mathrm{e}(\mathrm{cal})}$ values for $\mathrm{RE}$ ion sorption on PVC or CPB/PVC did not follow a pseudo-first-order kinetic model.

The pseudo-second-order kinetic model was introduced by [52-54]:

$$
\frac{\mathrm{t}}{\mathrm{q}_{\mathrm{t}}}=\frac{1}{\mathrm{k}_{2} \mathrm{q}_{\mathrm{e}}^{2}}+\frac{\mathrm{t}}{\mathrm{q}_{\mathrm{e}}}
$$

where $\mathrm{k}_{2}$ refers to the pseudo-second-order rate constant (g/mg.min). From the data in Figure 7c, the plots exhibited straight lines for PVC and CPB/PVC with a $\mathrm{R}^{2}$ of about 0.995 and 0.996 , respectively, nearly to unity. The sorption processes were right to the pseudo-second-order model, as observed in Table 2. Additionally, the proposed values ( $q_{c a l}$ ) of adsorbed amounts at equilibrium were close to the practical sorption uptakes $\left(q_{\text {exp }}\right)$. The data show that the RE ion sorption upon PVC or CPB/PVC well obeyed the pseudo-second-order kinetic model.

Table 2. Kinetic factors for REE sorption upon PVC and CPB/PVC sorbents.

\begin{tabular}{cccc}
\hline Kinetic Models & Parameters & PVC & CPB/PVC \\
\hline \multirow{3}{*}{ Pseudo-first-order } & $\mathrm{q}_{\mathrm{e}}(\mathrm{mg} / \mathrm{g})$ & 57.77 & 148.35 \\
& $\mathrm{k}_{1}(1 / \mathrm{min})$ & 0.075 & 0.039 \\
& $\mathrm{R}^{2}$ & 0.85 & 0.93 \\
\hline \multirow{3}{*}{ Pseudo-second-order } & $\mathrm{q}_{\mathrm{e}}(\mathrm{mg} / \mathrm{g})$ & 75.75 & 185.18 \\
& $\mathrm{~K}_{2}(\mathrm{~g} / \mathrm{md} \cdot \mathrm{min})$ & $1.01 \times 10^{-3}$ & $5.33 \times 10^{-4}$ \\
& $\mathrm{R}^{2}$ & 0.95 & 0.996 \\
\hline \multirow{2}{*}{ Elovich } & $\alpha(\mathrm{mg} / \mathrm{g} \cdot \mathrm{min})$ & 11.73 & 27.13 \\
& $\beta(\mathrm{g} / \mathrm{mg})$ & 0.0589 & 0.022 \\
Intra-particle & $\mathrm{R}^{2}$ & 0.881 & 0.956 \\
diffusion & $\mathrm{k}_{\mathrm{id}}\left(\mathrm{mg} / \mathrm{g} \cdot \mathrm{min}{ }^{1 / 2}\right)$ & 5.38 & 15.48 \\
& $\mathrm{I}(\mathrm{mg} / \mathrm{g})$ & 18.74 & 40.08 \\
Practical capacity & $\mathrm{R}^{2}$ & 0.705 & 0.849 \\
\hline
\end{tabular}

The Elovich kinetic model [55-57] designates the chemical sorption characteristic, and is generally a linear equation according to the following:

$$
\mathrm{q}_{\mathrm{t}}=\left[\left(\frac{1}{\beta}\right) \ln \alpha \beta\right]+\left[\left(\frac{1}{\beta}\right) \ln \mathrm{t}\right]
$$

where $\alpha$ corresponds to the initial sorption rate ( $\mathrm{mg} / \mathrm{g} \mathrm{min})$, while $\beta$ denotes the Elovich constant (g/mg). From Figure $7 \mathrm{~d}, \mathrm{R}^{2}$ was 0.881 and 0.956 for PVC and CPB/PVC, respectively. Hence, it was seen that the Elovich model was not suitable for the sorption processes.

The intraparticle model describes the correlation between the RE ion uptake $\left(q_{t}\right)$ sorbed at a time $(t)$ vs. the time square root $\left(t^{1 / 2}\right)$ linearly and can be expressed as [58]:

$$
\mathrm{q}_{\mathrm{t}}=\mathrm{k}_{\mathrm{id}} \mathrm{t}^{1 / 2}+\mathrm{I}
$$


where the $\mathrm{k}_{\mathrm{id}}$ symbolizes the initial rate constant $\left(\mathrm{mg} / \mathrm{g} \cdot \mathrm{min}^{1 / 2}\right)$ of intra-particle diffusion; and I provides a perception of the boundary layer thickness.

The $K_{\mathrm{id}}$ values were estimated using the intra-particle diffusion plot's slope, as seen in Figure $7 \mathrm{e}$. The $\mathrm{R}^{2}$ values $(0.705$ and 0.849$)$ showed that the intra-particle diffusion processes were not the rate-limiting stage of the PVC and CPB/PVC sorbents. The obtained parameters for this model are shown in Table 2. This means that intra-particle diffusion models would not be the rate-limiting stage.

\subsubsection{Effect of Initial REE Concentration}

The attained results featured in Figure 8a show that the uptake $\left(\mathrm{q}_{\mathrm{e}}, \mathrm{mg} / \mathrm{g}\right)$ of $\mathrm{RE}$ ions increased with increasing initial RE ions concentration. The maximum uptake was achieved at $200 \mathrm{mg} / \mathrm{L}$ of RE ions. The maximal loading amount of RE ions on the PVC and $\mathrm{CPB} / \mathrm{PVC}$ sorbents was 65.2 and $182.6 \mathrm{mg} / \mathrm{g}$, respectively. The loaded REE uptake $\left(\mathrm{q}_{\mathrm{e}}\right)$ was still constant after $200 \mathrm{mg} / \mathrm{L}$ because the two sorbents reached their maximum loading capacities (saturation capacities). RE ions filled all active sites of the two sorbents.
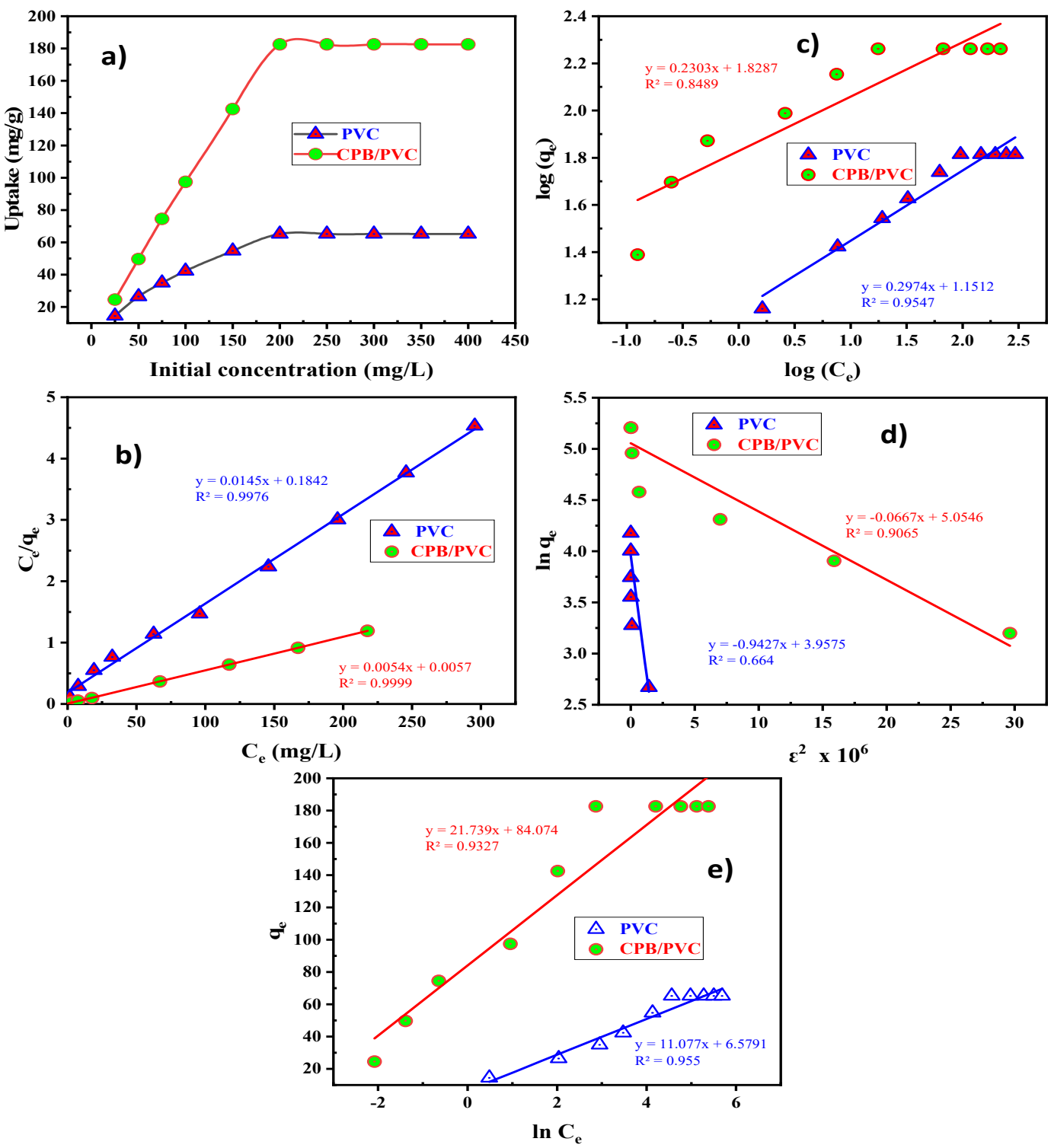

Figure 8. (a) Effect of initial REE concentration on REE uptake, (b) Langmuir, (c) Freundlich, (d) Dubinin and Radushkevich, and (e) Temkin isotherm models of REE sorption on PVC and CPB/PVC. 
Isotherm Characteristics

Studying the sorption isotherm models was necessary to discover the details of the sorption process such as the mechanism, surface properties, and other parameters that affect the sorption procedures.

In accordance with the Langmuir isotherm model, REs ion uptake occurs on a homogeneous surface through the monolayer of RE ions sorbed on the surface of PVC or CPB/PVC sorbents with steady sorption energy. In addition, there should be immobilization of the RE ions on the surface plane [59,60]. The linearized Langmuir isotherm model allowed for the intention of uptake capacity and Langmuir constant as follows:

$$
\frac{\mathrm{C}_{\mathrm{e}}}{\mathrm{q}_{\mathrm{e}}}=\frac{1}{\mathrm{q}_{\max } \mathrm{b}}+\frac{\mathrm{C}_{\mathrm{e}}}{\mathrm{q}_{\max }}
$$

where $C_{e}(\mathrm{mg} / \mathrm{L})$ refers to the equilibrium concentration in the aqueous layer, while $\mathrm{q}_{\mathrm{e}}$ and $\mathrm{q}_{\max }(\mathrm{mg} / \mathrm{g})$ are the equilibrium and the maximum amount sorbed per unit weight of sorbent, respectively; and $\mathrm{b}$ is a constant correlated to the ability of the binding sites and the sorption energy $(\mathrm{L} / \mathrm{mg})$.

The plots of $\mathrm{C}_{\mathrm{e}} / \mathrm{q}_{\mathrm{e}}$ vs. $\mathrm{C}_{\mathrm{e}}$ were tabulated in Table 3 and Figure $8 \mathrm{~b}$. From the obtained results, the calculated maximum capacities $(68.96$ and $185.18 \mathrm{mg} / \mathrm{g}$ ) corresponded more to the practical data $(65.13$ and $182.60 \mathrm{mg} / \mathrm{g})$, and the $\mathrm{R}^{2}$ was close to unity for both the PVC and CPB/PVC sorbents. Therefore, the working sorption process could obey the Langmuir sorption model.

Table 3. Isotherm restrictions of isotherm modeling for REE sorption upon the PVC and CPB/PVC sorbents.

\begin{tabular}{cccc}
\hline Isotherm Models & Parameters & PVC & CPB/PVC \\
\hline \multirow{3}{*}{ Langmuir } & $\mathrm{q}_{\mathrm{max}}(\mathrm{mg} / \mathrm{g})$ & 68.96 & 185.18 \\
& $\mathrm{~b}(\mathrm{~L} / \mathrm{mg})$ & 0.079 & 0.947 \\
& $\mathrm{R}^{2}$ & 0.997 & 0.999 \\
\hline \multirow{3}{*}{ Freundlich } & $\mathrm{K}_{\mathrm{f}}(\mathrm{mg} / \mathrm{g})$ & 14.16 & 67.41 \\
& $1 / \mathrm{n}(\mathrm{mg} \cdot \mathrm{min} / \mathrm{g})$ & 0.297 & 0.230 \\
& $\mathrm{R}^{2}$ & 0.955 & 0.849 \\
\hline \multirow{2}{*}{$\mathrm{D}-\mathrm{R}$} & $\mathrm{q}_{\mathrm{D}}(\mathrm{mg} / \mathrm{g})$. & 52.33 & 156.74 \\
& $\left.\mathrm{~B}_{\mathrm{D}}\left(\mathrm{mol}^{2} / \mathrm{kJ}\right)^{2}\right)$ & 0.943 & 0.067 \\
& $\mathrm{E}(\mathrm{kJ} / \mathrm{mol})$ & 0.728 & 2.738 \\
& $\mathrm{R}^{2}$ & 0.664 & 0.906 \\
\hline \multirow{2}{*}{ Temkin } & $\mathrm{b}_{\mathrm{T}}(\mathrm{J} / \mathrm{mol})$ & 223.67 & 113.97 \\
& $\mathrm{~K}_{\mathrm{T}}(\mathrm{L} / \mathrm{g})$ & 1.81 & 47.79 \\
& $\mathrm{R}^{2}$ & 0.955 & 0933 \\
\hline Practical capacity & $\mathrm{q}_{\exp }(\mathrm{mg} / \mathrm{g})$ & 65.13 & 182.60 \\
\hline
\end{tabular}

The Freundlich isotherm model was applied to explore the RE ion sorption on the studied sorbent's surface. It supposes that REE sorption takes place with various energetic layers of the active sites [61]. Equation (9) represents the Freundlich isotherm model:

$$
\log q_{e}=\log K_{f}+\left[\left(\frac{1}{n}\right) \log C_{e}\right]
$$

where $\mathrm{K}_{\mathrm{f}}(\mathrm{mg} / \mathrm{g})$ represents the constant related to overall RE ion sorption uptake and $\mathrm{n}$ is related to surface heterogeneity. The constant $n$ was deliberated at the slope of $\log \mathrm{q}_{\mathrm{e}}$ against the $\log \mathrm{C}_{\mathrm{e}}$ plot, as demonstrated in Figure $8 \mathrm{c} . \mathrm{K}_{\mathrm{f}}$ was calculated from the intercept simultaneously; the $\mathrm{K}_{\mathrm{f}}(\mathrm{mg} / \mathrm{g})$ values were less than the two sorbents' experimental capacity of RE ions. The $1 / \mathrm{n}$ values were less than 1.0 , demonstrating that $\mathrm{RE}$ ions preferred 
sorption by the PVC and CPB/PVC sorbents, while the $\mathrm{R}^{2}$ values were 0.955 and 0.849 ; this revealed that the Freundlich model also did not match the gained experimental results.

The Dubinin-Radushkevich (D-R) isotherm model offers a hypothetical distribution of energy sites. It is an excellent model to distinguish between physisorption and chemisorption [62,63]. It can be stated as follows:

$$
\ln \mathrm{q}_{\mathrm{e}}=\ln \mathrm{q}_{\mathrm{D}}-\mathrm{B}_{\mathrm{D}} \varepsilon^{2}
$$

where $\mathrm{q}_{\mathrm{D}}$ is the monolayer uptake $(\mathrm{mg} / \mathrm{g}) ; \mathrm{B}_{\mathrm{D}}\left(\mathrm{mol}^{2} / \mathrm{kJ}^{2}\right)$ is related to the sorption energy constant; and $\varepsilon$ represents the Polanyi potential correlated to the equilibrium concentration as the subsequent:

$$
\varepsilon=\mathrm{RT} \ln \left(1+\frac{1}{\mathrm{C}_{\mathrm{e}}}\right)
$$

where $\mathrm{T}$ corresponds to the absolute temperature $(\mathrm{K})$, and $\mathrm{R}$ is associated with the universal gas constant $(8.314 \mathrm{~J} / \mathrm{mol} . \mathrm{K})$. The following relation could calculate the free energy $(\mathrm{E})$ :

$$
\mathrm{E}=\frac{1}{\sqrt{2 \mathrm{~B}_{\mathrm{D}}}}
$$

where the $\mathrm{q}_{\mathrm{D}}$ and $\mathrm{B}_{\mathrm{D}}$ constants are inferred from the relation $\ln \mathrm{q}_{\mathrm{e}} \mathrm{vs} . \varepsilon^{2}$ plots (Table 3 and Figure $4 \mathrm{~d}$ ). The sorption process is chemical if the magnitude of $\mathrm{E}$ is in the variety of $8.0-16.0 \mathrm{~kJ} / \mathrm{mol}$ whereas the sorption process is physical if $\mathrm{E}$ is less than $8.0 \mathrm{~kJ} / \mathrm{mol}[36,37]$. The calculated E was less than $1.0 \mathrm{~kJ} / \mathrm{mol}$ for RE ion sorption of the two studied sorbents, demonstrating that $\mathrm{RE}$ ions sorption proceeds via physisorption. However, $\left(\mathrm{R}^{2}\right)$ values were 0.664 and 0.906 for PVC and CPB/PVC, respectively. Consequently, the (D-R) model did not suit the RE ion sorption on PVC and CPB/PVC.

The Temkin isotherm model postulated linear reduction in the sorption energy as the achievement rate of the sorption process toward the sorbent increases. Because of the sorbent-REEs interfaces, the sorption heat of all ions in the layer is regularly reduced with coverage. Moreover, the sorption process was described by a constant dispersal of binding energies, ready for maximum binding energy [64]. The Temkin isotherm could be indicated as follows:

$$
\mathrm{q}_{\mathrm{e}}=\left[\left(\frac{\mathrm{RT}}{\mathrm{b}_{\mathrm{T}}}\right) \ln \mathrm{K}_{\mathrm{T}}\right]+\left[\left(\frac{\mathrm{RT}}{\mathrm{b}_{\mathrm{T}}}\right) \ln \mathrm{C}_{\mathrm{e}}\right]
$$

where $b_{T}(\mathrm{~kJ} / \mathrm{mol})$ is defined as a constant interrelated to sorption heat; and $K_{T}(\mathrm{~L} / \mathrm{g})$ points to the equilibrium binding constant. Both $\mathrm{b}_{\mathrm{T}}$ and $\mathrm{K}_{\mathrm{T}}$ were obtained by plotting $\mathrm{q}_{\mathrm{e}} \mathrm{vs}$. $\ln \mathrm{C}_{\mathrm{e}}$ as shown in Table 3 and Figure 8e. From the obtained data, the values of $\mathrm{R}^{2}$ were 0.955 and 0.933 for the PVC and CPB/PVC sorbents, respectively. The data assumed that the sorption processes did not obey the Temkin isotherm model.

\subsubsection{Effect of Temperature}

The influence of system temperature on RE ion sorption was examined from $25-60{ }^{\circ} \mathrm{C}$. As demonstrated in Figure 9a, the REE sorption uptake of PVC and CPB/PVC diminished from 65.13 and $182.60 \mathrm{mg} / \mathrm{g}$ to 55.37 and $150.20 \mathrm{mg} / \mathrm{g}$ with an increase in the temperature due to the decomposition of the sorbent structure and decreased active sites. As a result, the ambient temperature was selected as the optimum temperature for RE ion sorption on the two sorbents. 

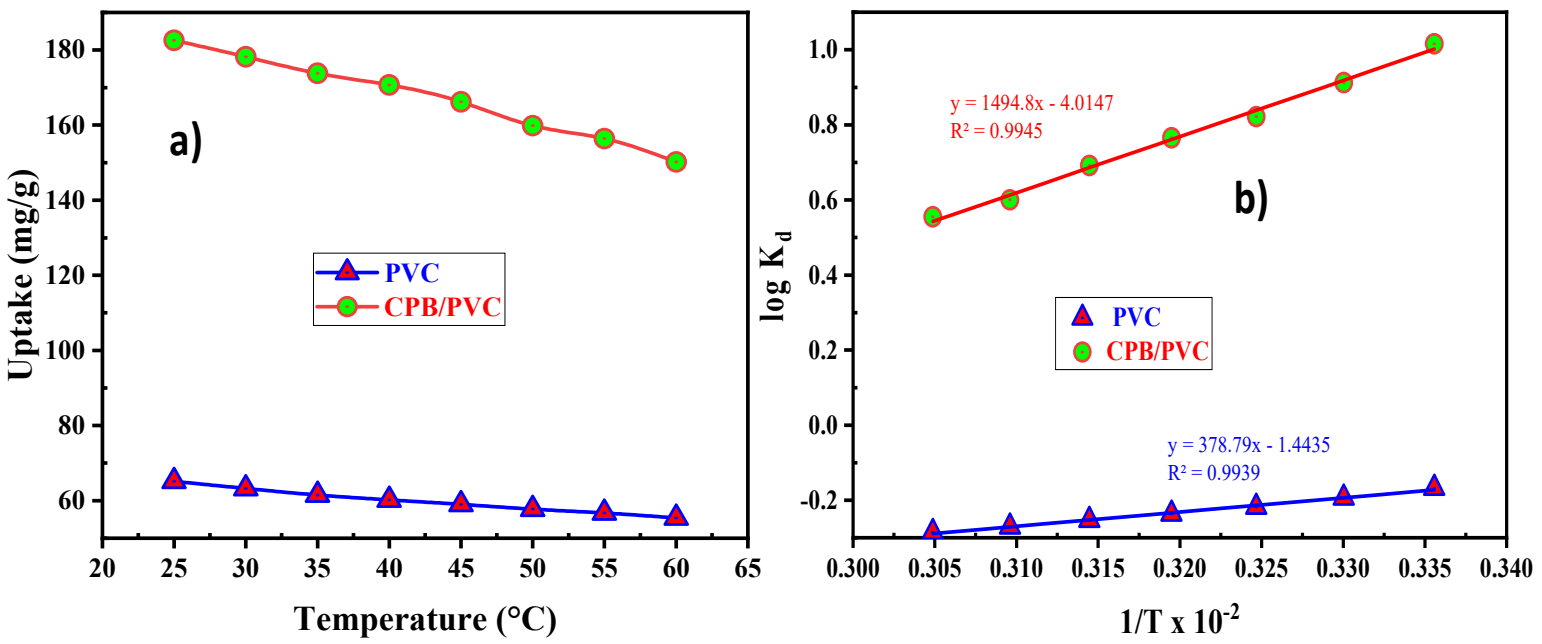

Figure 9. (a) Effect of temperature on REE uptake, and (b) $\log K_{d}$ vs. 1/T relation of REE sorption on $\mathrm{PVC}$, and CBP/ PVC.

Thermodynamic Studies

The effectiveness of temperature on the RE ions sorption process was examined to investigate the thermodynamic factors and identify the nature of the sorption process. It was detected that the sorption efficiencies of the two sorbents were reduced with an increase in temperature. The experimental data were utilized to determine the change in entropy $\left(\Delta S^{\circ}\right)$, enthalpy $\left(\Delta \mathrm{H}^{\circ}\right)$, and thermodynamic parameters of RE ions sorption on $\mathrm{PVC}$ and $\mathrm{CPB} / \mathrm{PVC}$ were described from successive equations [65-67].

$$
\begin{gathered}
\log \mathrm{K}_{\mathrm{d}}=\frac{\Delta \mathrm{S}^{\circ}}{2.303 \mathrm{R}}-\frac{\Delta \mathrm{H}^{\circ}}{2.303 \mathrm{RT}} \\
\Delta \mathrm{G}^{\circ}=\Delta \mathrm{H}^{\circ}-\mathrm{T} \Delta \mathrm{S}^{\circ}
\end{gathered}
$$

where $\mathrm{K}_{\mathrm{d}}$ refers to the $\mathrm{RE}$ ion sorption constant $(\mathrm{L} / \mathrm{g}) ; \Delta \mathrm{H}^{\circ}$ is the enthalpy changes $(\mathrm{kJ} / \mathrm{mol})$; $\Delta \mathrm{S}^{\circ}$ symbolizes for the changes in the entropy of RE ions sorption (J/mol.K); $\Delta \mathrm{G}^{\circ}$ corresponds to Gibbs free energy ( $\mathrm{kJ} / \mathrm{mol})$; and T represents the absolute temperature (K). Both $\Delta \mathrm{S}^{\circ}$ and $\Delta \mathrm{H}^{\circ}$ can be gained from the intercept and slope of $\log \mathrm{K}_{\mathrm{d}}$ vs. $1 / \mathrm{T}$ plot (Figure $9 \mathrm{~b}$ ). The $\Delta \mathrm{H}^{\circ}, \Delta \mathrm{S}^{\circ}$, and $\Delta \mathrm{G}^{\circ}$ values for the two sorbents can be found in Table 4 . The positive $\Delta \mathrm{G}^{\circ}$ values of the PVC sorbent proved that the RE ion sorption process is non-spontaneous. Nonetheless, the negative $\Delta G^{\circ}$ value verified the spontaneous behavior of $R E$ ion sorption on the CBP/PVC. Furthermore, the process was favorable for forming an electrostatic interaction between RE ions and CBP/PVC sorbent.

Table 4. Thermodynamic parameters of REE sorption on the PVC and CPB/PVC.

\begin{tabular}{cccc}
\hline Parameters & Temperature, K & PVC & CPB/PVC \\
\hline \multirow{2}{*}{$\Delta \mathrm{G}^{\circ}, \mathrm{kJ} / \mathrm{mol}$} & 298.0 & 0.9748 & -5.7038 \\
& 303.0 & 1.1128 & -5.3193 \\
& 308.0 & 1.2508 & -4.9348 \\
& 313.0 & 1.3888 & -4.5503 \\
& 318.0 & 1.5268 & -4.1658 \\
& 323.0 & 1.6648 & -3.7813 \\
& 328.0 & 1.8028 & -3.3968 \\
$\Delta \mathrm{H}^{\circ}, \mathrm{kJ} / \mathrm{mol}$ & 333.0 & 1.9408 & -3.0123 \\
\hline$\Delta \mathrm{S}^{\circ}, \mathrm{kJ} / \mathrm{mol} . \mathrm{K}$ & & -7.25 & -28.62 \\
\hline
\end{tabular}


The negative $\Delta \mathrm{H}^{\circ}$ values might propose the exothermic sorption process. Additionally, the negative $\Delta S^{\circ}$ values indicated the probability of the sorption processes and the decrease in randomness at the connection point between the sorbent/sorbate during the sorption processes of RE ions on PVC and CPB/PVC.

\subsection{Desorption Studies}

The desorption of metal ions is decisive in designing a sorption system; this step is intended to improve the desired metal ion concentration for final recovery. Moreover, this process is also vital in testing the recyclability of the sorbent, which is a significant feature for economic competitiveness.

\subsubsection{Type of Eluting Agent}

Impact of eluting agents on the desorption process of rare earth ions from the loaded $\mathrm{PVC}$ and $\mathrm{CPB} / \mathrm{PVC}$ was explored through the batch technique by shaking different eluting agents $\left(\mathrm{NaCl}, \mathrm{HCl}, \mathrm{HNO}_{3}\right.$, and $\left.\mathrm{H}_{2} \mathrm{SO}_{4}\right)$ while the other parameters were still constant at $0.5 \mathrm{M}$ of the eluting agent at a $1: 50 \mathrm{~S}: \mathrm{L}$ phase ratio $(0.1 \mathrm{~g}$ of sorbent and $5.0 \mathrm{~mL}$ of eluting agent) for $30 \mathrm{~min}$ at ambient temperature. As seen in Figure 10a, it was observed that the desorption efficiency of RE ions from loaded PVC or CBP/PVC using $0.5 \mathrm{M}$ hydrochloric acid reached maximum desorption efficiencies, attaining 57.5 and $62.4 \%$, respectively. Therefore, it was concluded that hydrochloric acid can be used to desorb REEs quantitatively from the surfaces of the two sorbents.
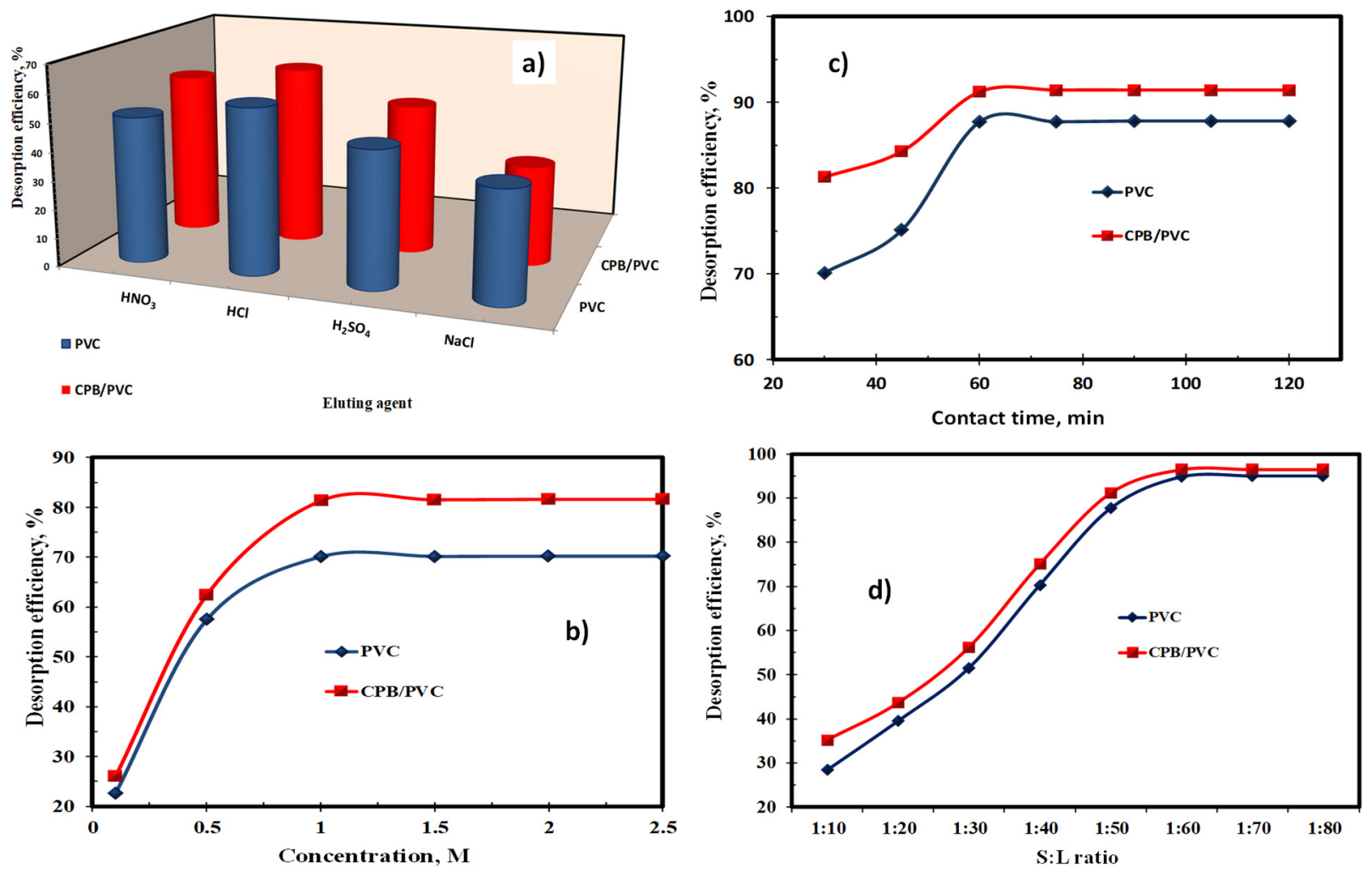

Figure 10. Effect of (a) eluting agents, (b) $\mathrm{HCl}$ concentration, (c) desorption time, and (d) S:L ratio upon REE desorption efficiency for the PVC and CBP/PVC sorbents.

\subsection{2. $\mathrm{HCl}$ Concentration}

The REE stripping from their loaded sorbents was studied using a concentration range of $\mathrm{HCl}$ from $0.1-2.5 \mathrm{M}$. The other factors were kept constant using $0.1 \mathrm{~g}$ loaded sorbents and $5.0 \mathrm{~mL}$ of the eluting solution for $30 \mathrm{~min}$ at $25^{\circ} \mathrm{C}$ room temperature. The gained data represented in Figure 10b illustrates that the desorption efficacy of RE ions 
improved with an increase in the concentration of $\mathrm{HCl}$ up to $1.0 \mathrm{M}$. In contrast, the optimum values of desorption were achieved at 70.1 and $81.3 \%$ for the PVC and CBP/PVC sorbents, respectively. Consequently, it can be concluded that $1.0 \mathrm{M} \mathrm{HCl}$ is recommended for the elution process of rare earth ions.

\subsubsection{Desorption Time}

The influence of desorption time on the RE ion desorption was examined. For this purpose, $0.1 \mathrm{~g}$ REE/sorbent (REE/PVC, or REE/CPB/PVC) were mixed with $5.0 \mathrm{~mL}$ of $1.0 \mathrm{M} \mathrm{HCl}$ by different contact times ranging from 30 to $120 \mathrm{~min}$ at ambient temperature. According to the data represented in Figure 10c, it was clear that 60 min of contact time was required for the maximum RE ion desorption efficiencies at $87.7 \%$ and $91.2 \%$ for the PVC and CPB/PVC sorbents, respectively.

\subsubsection{S:L Phase Ratio}

The influence of S:L phase ratio on REE desorption from their loaded sorbents was examined in the range of 1:10 to 1:80 to investigate the minimum volume of eluting agent required. It was observed that the rare earth ion desorption efficiency was improved by raising the S:L ratio to 1:60; following this, the REE desorption efficiencies were nearly constant at 94.8 and $96.5 \%$ for the PVC and CBP/PVC sorbents, respectively (Figure 10d). Therefore, the 1:60 S:L ratio of the studied sorbents was optimized for the subsequent experiments.

\subsection{Regeneration}

The PVC or CBP/PVC were regenerated by $1.0 \mathrm{M}$ of $\mathrm{HCl}$ and 1:60 S:L ratio at room temperature for $60 \mathrm{~min}$ contact time to be recycled and reused to another sorption experiment. The sorption and desorption processes were recurrent until the desorption efficiency was decreased from 94.8 and $96.5 \%$ to 76.0 and $78.0 \%$ for the PVC and CBP/PVC, respectively, after eight consecutive sequences. It was decided that there was good sorption constancy of the two considered sorbents for REE recovery.

\subsection{Case Study}

The studied sample consisted of lamprophyre dikes collected from the area of Abu Rusheid in the South-Eastern Desert of Egypt. Lamprophyre dikes are mainly comprised of kaolinite, muscovite, K-feldspars, quartz, biotite, and plagioclases [68]. The sample of lamprophyre dikes was wholly analyzed by suitable techniques to specify major as well as trace ions. The data clearly show that analysis of $\mathrm{SiO}_{2}, \mathrm{Fe}_{2} \mathrm{O}_{3}, \mathrm{Al}_{2} \mathrm{O}_{3}, \mathrm{~K}_{2} \mathrm{O}, \mathrm{CaO}$, and $\mathrm{P}_{2} \mathrm{O}_{5}$ assayed $46.3,15.36,16.8,2.8,2.3$, and $1.02 \%$, respectively. The sample had $3274 \mathrm{mg} / \mathrm{kg}$ of yttrium and $400 \mathrm{mg} / \mathrm{kg}$ of uranium. Furthermore, individual rare earth ions were analyzed using the ICP-OES technique (Table 5) [69].

The leach liquor of REEs was prepared by treating $2.0 \mathrm{~kg}$ of a milled sample of lamprophyre dike with $8.0 \mathrm{~L}$ of $3.0 \mathrm{M} \mathrm{HCl}$ for $3.0 \mathrm{~h}$ at ambient temperature [69]. The residue was then filtered, and the leach solution was analyzed, as shown in Tables 6 and 7.

After preparing and analyzing leach liquor according to the studied optimum condition, PVC and CBP/PVC were used to carefully remove rare earth ions from the treated leachate under optimal conditions. Furthermore, the sorption efficiencies of 48.1 and $87.5 \%$ were obtained for PVC and CPB/PVC, respectively. The REE sorption efficiency from leach liquor was slightly lower than the maximum sorption efficiency of PVC and CBP/PVC sorbents from the pure synthetic solution due to impurities in leach liquor. 
Table 5. Chemical analysis of lamprophyre dike ore.

\begin{tabular}{cc|cc|cc}
\hline Major Oxides & Wt., $\%$ & Metal Ions & mg/kg & REE Ions & mg/kg \\
\hline $\mathrm{SiO}_{2}$ & 46.30 & $\mathrm{U}^{6+}$ & 400 & $\mathrm{Y}^{3+}$ & 3274 \\
$\mathrm{Al}_{2} \mathrm{O}_{3}$ & 16.80 & $\mathrm{Ba}^{2+}$ & 167 & $\mathrm{Ce}^{3+}$ & 160 \\
$\mathrm{Fe}_{2} \mathrm{O}_{3}$ & 15.36 & $\mathrm{~Pb}^{2+}$ & 596 & $\mathrm{La}^{3+}$ & 90 \\
$\mathrm{TiO}_{2}$ & 3.40 & $\mathrm{~V}^{5+}$ & 240 & $\mathrm{Nd}^{3+}$ & 143 \\
$\mathrm{~K}_{2} \mathrm{O}$ & 2.80 & $\mathrm{Cu}^{2+}$ & 367 & $\mathrm{Sm}^{3+}$ & 26 \\
$\mathrm{Na}_{2} \mathrm{O}$ & 0.48 & $\mathrm{Ni}^{2+}$ & 86.7 & $\mathrm{Gd}^{3+}$ & 60 \\
$\mathrm{CaO}$ & 2.30 & $\mathrm{Cd}^{2+}$ & 49.5 & $\mathrm{Ho}^{3+}$ & 171 \\
$\mathrm{MnO}$ & 0.65 & $\mathrm{Zn}^{2+}$ & 6348 & $\mathrm{Er}^{3+}$ & 145 \\
$\mathrm{P}_{2} \mathrm{O}$ & $\mathrm{Th}^{4+}$ & 39 & $\mathrm{Yb}^{3+}$ & 550 \\
$\mathrm{MgO}$ & 1.02 & & & $\mathrm{Lu}^{3+}$ & $\mathrm{Pr}^{3+}$ \\
$\mathrm{LOI}$ & 0.06 & & & \\
Total & 8.75 & & & & 170
\end{tabular}

LOI*: Loss of ignition $\left(1000^{\circ} \mathrm{C}\right)$

Table 6. Chemical investigation of metal ions in the leach liquor.

\begin{tabular}{cccc}
\hline Metal Ions & Conc. $(\mathrm{g} / \mathrm{L})$ & Metal Ions & Conc. (mg/L) \\
\hline $\mathrm{Si}^{4+}$ & 1.35 & $\mathrm{U}^{6+}$ & 94.0 \\
$\mathrm{Al}^{3+}$ & 2.34 & $\mathrm{REEs}$ & 1140.0 \\
$\mathrm{Ti}^{4+}$ & 0.32 & $\mathrm{Ba}^{2+}$ & 44.0 \\
$\mathrm{Fe}^{3+}$ & 3.57 & $\mathrm{~Pb}^{2+}$ & 103.0 \\
$\mathrm{Mn}^{2+}$ & 0.50 & $\mathrm{~V}^{5+}$ & 51.0 \\
$\mathrm{Mg}^{2+}$ & 0.31 & $\mathrm{Cu}^{2+}$ & 85.0 \\
$\mathrm{Ca}^{2+}$ & 0.67 & $\mathrm{Ni}^{2+}$ & 19.0 \\
$\mathrm{~K}^{+}$ & 0.73 & $\mathrm{Th}^{4+}$ & 5.0 \\
$\mathrm{Na}^{+}$ & 0.99 & $\mathrm{Zn}^{2+}$ & 620.0 \\
$\mathrm{P}^{5+}$ & 0.12 & & \\
\hline
\end{tabular}

Table 7. Chemical investigation of RE ions in the leach liquor.

\begin{tabular}{cccc}
\hline Metal Ions & Conc. $(\mathbf{m g} / \mathrm{L})$ & Metal Ions & Conc. $(\mathbf{m g} / \mathrm{L})$ \\
\hline $\mathrm{La}^{3+}$ & 21.0 & $\mathrm{~Tb}^{3+}$ & 0.0 \\
$\mathrm{Ce}^{3+}$ & 37.0 & $\mathrm{Dy}^{3+}$ & 0.0 \\
$\mathrm{Pr}^{3+}$ & 40.0 & $\mathrm{Ho}^{3+}$ & 40.0 \\
$\mathrm{Nd}^{3+}$ & 34.0 & $\mathrm{Er}^{3+}$ & 34.0 \\
$\mathrm{Sm}^{3+}$ & 6.0 & $\mathrm{Tm}^{3+}$ & 0.0 \\
$\mathrm{Eu}^{3+}$ & 0.0 & $\mathrm{Yb}^{3+}$ & 129.0 \\
$\mathrm{Gd}^{3+}$ & 14.0 & $\mathrm{Lu}^{3+}$ & 16.0 \\
$\mathrm{Y}^{3+}$ & 769.0 & &
\end{tabular}

Loaded sorbents (REE/PVC and REE/CPB/PVC) were subjected to desorption under the studied optimum conditions $\left(1.0 \mathrm{M} \mathrm{HCl}, 1: 60 \mathrm{~S}: \mathrm{L}\right.$ ratio, $60 \mathrm{~min}$ desorption time, $\left.25^{\circ} \mathrm{C}\right)$. Desorption efficiencies of 94.8 and $96.5 \%$ of REE/PVC and REE/CPB/PVC were obtained, respectively. After desorption and preconcentration, oxalic acid was used to precipitate RE ions as RE oxalates. The RE ions were precipitated using $20.0 \%$ oxalic acid $\left(\mathrm{H}_{2} \mathrm{C}_{2} \mathrm{O}_{4}\right)$ as a rare earth oxalate precipitate [70,71]. The obtained precipitates of the two sorbents were analyzed and confirmed using SEM-EDX along with ICP-OES to detect their individual REEs distribution, as presented in Table 8 and Figure 11. 
Table 8. Chemical analysis of RE oxalate products obtained from REEs loaded on two sorbents using ICP-OES.

\begin{tabular}{ccc}
\hline \multirow{2}{*}{ Metal Ions } & \multicolumn{2}{c}{ Conc. $(\mathbf{m g} / \mathbf{k g})$} \\
\cline { 2 - 3 } & PVC & CPB/PVC \\
\hline $\mathrm{La}^{3+}$ & 2415.394 & 7171.722 \\
$\mathrm{Ce}^{3+}$ & 4546.624 & $13,499.71$ \\
$\mathrm{Pr}^{3+}$ & 4830.788 & $14,343.44$ \\
$\mathrm{Nd}^{3+}$ & 4120.378 & $12,234.11$ \\
$\mathrm{Sm}^{3+}$ & 568.328 & 1687.464 \\
$\mathrm{Gd}^{3+}$ & 1776.025 & 5273.325 \\
$\mathrm{Ho}^{3+}$ & 4901.829 & $14,554.38$ \\
$\mathrm{Yb}^{3+}$ & $17,476.09$ & $51,889.52$ \\
$\mathrm{Lu}^{3+}$ & 1989.148 & 5906.124 \\
$\mathrm{Y}^{3+}$ & $99,457.4$ & $295,306.2$ \\
$\mathrm{Total}^{3+}$ & 142,082 & 421,866 \\
\hline
\end{tabular}
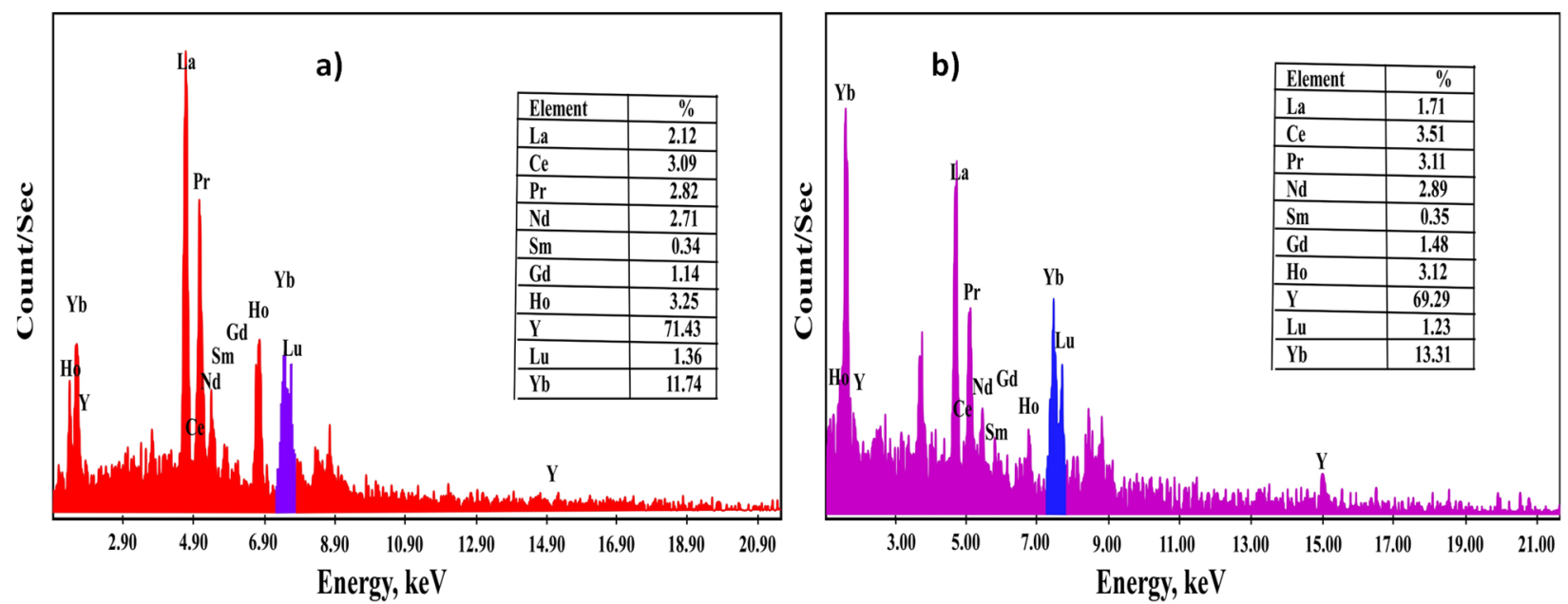

Figure 11. (a) The environmental scanning electron microscope of rare earth oxalate from REEs/PVC. (b) The environmental scanning electron microscope of rare earth oxalate from REEs/CBP/PVC.

\section{Conclusions}

Polyvinyl chloride was treated with cetylpyridinium bromide to obtain a highly efficient, low-cost sorbent with outstanding results for RE ion sorption. The PVC and CPB/PVC were utilized to enhance the RE ion uptake from a chloride solution. The optimum sorption conditions were $\mathrm{pH}$ 6.0, 60 min equilibrium time, and $25^{\circ} \mathrm{C}$. The uptake of RE ions upon PVC and CPB/PVC were 65.13 and $182.6 \mathrm{mg} / \mathrm{g}$, respectively. The RE ion sorption well obeyed the Langmuir isotherm model, and the pseudo-second-order model proved that the sorption occurred through chemical interaction. Additionally, the thermodynamic studies proved that the sorption of RE ions was exothermic and spontaneous for the CPB/PVC sorbent, and the maximum elution of RE ions from the loaded sorbent was obtained at the 1:60 S:L ratio and $1.0 \mathrm{M} \mathrm{HCl}$ for $60 \mathrm{~min}$ at ambient temperature. Thus, the CPB/PVC sorbent was recognized as a competitive sorbent for REE recovery.

Author Contributions: Conceptualization, E.M.A. and M.A.H.; Methodology, E.M.A. and M.A.H.; Software, E.M.A., A.K.S., and M.F.C.; Validation, M.Y.H. and M.I.S.; Formal analysis, E.M.A.; Investigation, E.M.A., A.K.S., and M.A.H.; Resources, E.M.A.; Data curation, E.M.A., and A.K.S.; Writing—original draft preparation, E.M.A.; Writing—review and editing, E.M.A., A.K.S., and M.F.C.; Visualization, E.M.A. and M.F.C.; Supervision, M.A.H., M.F.C., T.A.L., and S.A.A.E.-E.; Project administration, T.A.L., and S.A.A.E.-E.; Funding acquisition, J.S.A.-O. All authors have read and agreed to the published version of the manuscript. 
Funding: The authors express their gratitude to Princess Nourah bint Abdulrahman University Researchers Supporting Project number (PNURSP2022R13), Princess Nourah bint Abdulrahman University, Riyadh, Saudi Arabia.

Institutional Review Board Statement: Not applicable.

Informed Consent Statement: Not applicable.

Data Availability Statement: Not applicable.

Acknowledgments: The authors express their gratitude to Princess Nourah bint Abdulrahman University Researchers Supporting Project number (PNURSP2022R13), Princess Nourah bint Abdulrahman University, Riyadh, Saudi Arabia.

Conflicts of Interest: The authors declare no conflict of interest.

\section{References}

1. Yang, X.; Salvador, D.; Makkonen, H.T.; Pakkanen, L. Phosphogypsum Processing for Rare Earths Recovery-A Review. Nat. Resour. 2019, 10, 325-336. [CrossRef]

2. Bau, M.; Dulski, P. Comparative study of yttrium and rare earth element behaviors in fluorine-rich hydrothermal fluids. Contrib. Mineral. Petrol. 1995, 119, 213-223. [CrossRef]

3. Wang, X.; Lei, Y.; Ge, J.; Wu, S. Production forecast of China's rare earths based on the Generalized Weng model and policy recommendations. Resour. Policy 2015, 43, 11-18. [CrossRef]

4. Cheira, M.F.; Mira, H.I.; Sakr, A.K.; Mohamed, S.A. Adsorption of U(VI) from acid solution on a low-cost sorbent: Equilibrium, kinetic, and thermodynamic assessments. Nucl. Sci. Tech. 2019, 30, 156. [CrossRef]

5. Sakr, A.K.; Mohamed, S.A.; Mira, H.I.; Cheira, M.F. Successive leaching of uranium and rare earth elements from El Sela mineralization. J. Sci. Eng. Res. 2018, 5, 95-111.

6. Moustafa, M.I.; Abdelfattah, N.A. Physical and Chemical Beneficiation of the Egyptian Beach Monazite. Resour. Geol. 2010, 60, 288-299. [CrossRef]

7. Wu, S.; Bie, C.; Su, H.; Gao, Y.; Sun, X. The effective separation of yttrium and other heavy rare earth elements with salicylic acid derivatives. Miner. Eng. 2022, 178, 107396. [CrossRef]

8. Alakhras, F.A.; Dari, K.A.; Mubarak, M.S. Synthesis and chelating properties of some poly(amidoxime-hydroxamic acid) resins toward some trivalent lanthanide metal ions. J. Appl. Polym. Sci. 2005, 97, 691-696. [CrossRef]

9. Jeon, J.H.; Yoon, H.-S.; Kim, C.-J.; Chung, K.W.; Jyothi, R.K. Environmentally sound technology development for processing of rare earth elements from waste permanent magnets synthetic leach solutions: Recovery and separation perspectives. Sep. Purif. Technol. 2021, 275, 119225. [CrossRef]

10. Sakr, A.K.; Cheira, M.F.; Hassanin, M.A.; Mira, H.I.; Mohamed, S.A.; Khandaker, M.U.; Osman, H.; Eed, E.M.; Sayyed, M.I.; Hanfi, M.Y. Adsorption of Yttrium Ions on 3-Amino-5-Hydroxypyrazole Impregnated Bleaching Clay, a Novel Sorbent Material. Appl. Sci. 2021, 11, 10320. [CrossRef]

11. Alcaraz, L.; Largo, O.R.; Alguacil, F.J.; Montes, M.Á.; Baudín, C.; López, F.A. Extraction of Lanthanum Oxide from Different Spent Fluid Catalytic Cracking Catalysts by Nitric Acid Leaching and Cyanex 923 Solvent Extraction Methods. Metals 2022, 12, 378. [CrossRef]

12. García, A.C.; Latifi, M.; Amini, A.; Chaouki, J. Separation of Radioactive Elements from Rare Earth Element-Bearing Minerals. Metals 2020, 10, 1524. [CrossRef]

13. Liu, C.; Yan, Q.; Zhang, X.; Lei, L.; Xiao, C. Efficient Recovery of End-of-Life NdFeB Permanent Magnets by Selective Leaching with Deep Eutectic Solvents. Environ. Sci. Technol. 2020, 54, 10370-10379. [CrossRef] [PubMed]

14. Zhang, W.; Feng, D.; Xie, X.; Tong, X.; Du, Y.; Cao, Y. Solvent extraction and separation of light rare earths from chloride media using HDEHP-P350 system. J. Rare Earth. 2022, 40, 328-337. [CrossRef]

15. Moldoveanu, G.; Papangelakis, V. Chelation-Assisted Ion-Exchange Leaching of Rare Earths from Clay Minerals. Metals 2021, 11, 1265. [CrossRef]

16. Choubey, P.K.; Singh, N.; Panda, R.; Jyothi, R.K.; Yoo, K.; Park, I.; Jha, M.K. Development of Hydrometallurgical Process for Recovery of Rare Earth Metals (Nd, Pr, and Dy) from Nd-Fe-B Magnets. Metals 2021, 11, 1987. [CrossRef]

17. Chen, Z.; Li, Z.; Chen, J.; Kallem, P.; Banat, F.; Qiu, H. Recent advances in selective separation technologies of rare earth elements: A review. J. Environ. Chem. Eng. 2022, 10, 107104. [CrossRef]

18. Jia, Q.; Tong, S.; Li, Z.; Zhou, W.; Li, H.; Meng, S. Solvent extraction of rare earth elements with mixtures of sec-octylphenoxy acetic acid and bis(2,4,4-trimethylpentyl) dithiophosphinic acid. Sep. Purif. Technol. 2009, 64, 345-350. [CrossRef]

19. Jorjani, E.; Shahbazi, M. The production of rare earth elements group via tributyl phosphate extraction and precipitation stripping using oxalic acid. Arab. J. Chem. 2016, 9, S1532-S1539. [CrossRef]

20. Khawassek, Y.K.; Eliwa, A.A.; Gawad, E.A.; Abdo, S.M. Recovery of rare earth elements from El-Sela effluent solutions Peer review under responsibility of The Egyptian Society of Radiation Sciences and Applications. J. Radiat. Res. Appl. Sci. 2015, 8, 583-589. [CrossRef] 
21. Hamza, M.F.; Salih, K.A.M.; Abdel-Rahman, A.A.H.; Zayed, Y.E.; Wei, Y.; Liang, J.; Guibal, E. Sulfonic-functionalized algal/PEI beads for scandium, cerium and holmium sorption from aqueous solutions (synthetic and industrial samples). Chem. Eng. J. 2021, 403, 126399. [CrossRef]

22. Raju, C.S.K.; Subramanian, M.S. A novel solid phase extraction method for separation of actinides and lanthanides from high acidic streams. Sep. Purif. Technol. 2007, 55, 16-22. [CrossRef]

23. Helaly, O.S.; Abd El-Ghany, M.S.; Moustafa, M.I.; Abuzaid, A.H.; Abd El-Monem, N.M.; Ismail, I.M. Extraction of cerium(IV) using tributyl phosphate impregnated resin from nitric acid medium. Trans. Nonferrous Met. Soc. China 2012, 22, 206-214. [CrossRef]

24. Dave, S.R.; Kaur, H.; Menon, S.K. Selective solid-phase extraction of rare earth elements by the chemically modified Amberlite XAD-4 resin with azacrown ether. React. Funct. Polym. 2010, 70, 692-698. [CrossRef]

25. Jain, V.K.; Pandya, R.A.; Pillai, S.G.; Agrawal, Y.K.; Kanaiya, P.H. Solid-phase extractive preconcentration and separation of lanthanum(III) and cerium(III) using a polymer-supported chelating calix [4] arene resin. J. Anal. Chem. 2007, 62, 104-112. [CrossRef]

26. Nishihama, S.; Kohata, K.; Yoshizuka, K. Separation of lanthanum and cerium using a coated solvent-impregnated resin. Sep. Purif. Technol. 2013, 118, 511-518. [CrossRef]

27. Wang, Z.H.; Ma, G.X.; Lu, J.; Liao, W.P.; Li, D.Q. Separation of heavy rare earth elements with extraction resin containing 1-hexyl-4-ethyloctyl isopropylphosphonic acid. Hydrometallurgy 2002, 66, 95-99. [CrossRef]

28. Yadav, K.K.; Singh, D.K.; Anitha, M.; Varshney, L.; Singh, H. Studies on separation of rare earths from aqueous media by polyethersulfone beads containing D2EHPA as extractant. Sep. Purif. Technol. 2013, 118, 350-358. [CrossRef]

29. Lee, G.S.; Uchikoshi, M.; Mimura, K.; Isshiki, M. Separation of major impurities Ce, Pr, Nd, Sm, Al, Ca, Fe, and Zn from La using bis(2-ethylhexyl)phosphoric acid (D2EHPA)-impregnated resin in a hydrochloric acid medium. Sep. Purif. Technol. 2010, 71, 186-191. [CrossRef]

30. Saito, T.; Sato, H.; Motegi, T. Recovery of rare earths from sludges containing rare-earth elements. J. Alloy Compd. 2006, 425, 145-147. [CrossRef]

31. Soe, N.N.; Shwe, L.T.; Lwin, K.T. Study on Extraction of Lanthanum Oxide from Monazite Concentrate. World Acad. Sci. Eng. Technol. Int. J. Chem. Mol. Nucl. Mater. Metall. Eng. 2008, 2, 226-229.

32. Ogata, T.; Narita, H.; Tanaka, M. Adsorption behavior of rare earth elements on silica gel modified with diglycol amic acid. Hydrometallurgy 2015, 152, 178-182. [CrossRef]

33. Helfferich, F.G. Ion. Exchange; Courier Corporation: Chelmsford, MA, USA, 1995.

34. Marczenko, Z.; Balcerzak, M. Chapter 39-Rare-earth elements. In Analytical Spectroscopy Library; Marczenko, Z., Balcerzak, M., Eds.; Elsevier: Amsterdam, The Netherlands, 2000; Volume 10, pp. 341-349.

35. Lahsen, T.; Mohamed, S.; Cheira, M.; Zaki, D.; Allam, E. Leaching and Recovery of Rare Earth Elements from Altered Alkaline Granite Rock from Nusab El-Balgum Area, South Western Desert, Egypt. Res. Artic. 2016, 4, 787-801.

36. Cheira, M.F.; Rashed, M.N.; Mohamed, A.E.; Zidan, I.H.; Awadallah, M.A. The performance of Alizarin impregnated bentonite for the displacement of some heavy metals ions from the wet phosphoric acid. Sep. Sci. Technol. 2020, 55, 3072-3088. [CrossRef]

37. Cheira, M.F.; Rashed, M.N.; Mohamed, A.E.; Hussein, G.M.; Awadallah, M.A. Removal of some harmful metal ions from wet-process phosphoric acid using murexide-reinforced activated bentonite. Mater. Today Chem. 2019, 14, 100176. [CrossRef]

38. Cheira, M.F. Performance of poly sulfonamide/nano-silica composite for adsorption of thorium ions from sulfate solution. SN Appl. Sci. 2020, 2, 398. [CrossRef]

39. Behboudi, A.; Jafarzadeh, Y.; Yegani, R. Polyvinyl chloride/polycarbonate blend ultrafiltration membranes for water treatment. J. Membr. Sci. 2017, 534, 18-24. [CrossRef]

40. Ahmad, N.; Kausar, A.; Muhammad, B. An investigation on 4-aminobenzoic acid modified polyvinyl chloride/graphene oxide and PVC/graphene oxide based nanocomposite membranes. J. Plast. Film Sheet. 2016, 32, 419-448. [CrossRef]

41. Li, L.; Sakr, A.K.; Schlöder, T.; Klein, S.; Beckers, H.; Kitsaras, M.-P.; Snelling, H.V.; Young, N.A.; Andrae, D.; Riedel, S. Searching for Monomeric Nickel Tetrafluoride: Unravelling Infrared Matrix Isolation Spectra of Higher Nickel Fluorides. Angew. Chem. Int. Ed. 2021, 60, 6391-6394. [CrossRef]

42. Sneddon, G.; McGlynn, J.C.; Neumann, M.S.; Aydin, H.M.; Yiu, H.H.P.; Ganin, A.Y. Aminated poly(vinyl chloride) solid state adsorbents with hydrophobic function for post-combustion $\mathrm{CO}_{2}$ capture. J. Mater. Chem. A 2017, 5, 11864-11872. [CrossRef]

43. Giannoukos, K.; Salonitis, K. Study of the mechanism of friction on functionally active tribological Polyvinyl Chloride (PVC) Aggregate composite surfaces. Tribol. Int. 2020, 141, 105906. [CrossRef]

44. Salih, K.A.M.; Hamza, M.F.; Mira, H.; Wei, Y.; Gao, F.; Atta, A.M.; Fujita, T.; Guibal, E. Nd(III) and Gd(III) Sorption on Mesoporous Amine-Functionalized Polymer/SiO2 Composite. Molecules 2021, 26, 1049. [CrossRef]

45. Parameshwaran, R.; Sarı, A.; Jalaiah, N.; Karunakaran, R. Chapter 13-Applications of Thermal Analysis to the Study of PhaseChange Materials. In Handbook of Thermal Analysis and Calorimetry; Vyazovkin, S., Koga, N., Schick, C., Eds.; Elsevier Science, B.V.: Amsterdam, The Netherlands, 2018; Volume 6, pp. 519-572.

46. Lv, Y.; Liu, J.; Luo, Z.; Wang, H.; Wei, Z. Construction of chain segment structure models, and effects on the initial stage of the thermal degradation of poly(vinyl chloride). RSC Adv. 2017, 7, 37268-37275. [CrossRef]

47. Roy, K.J.; Anjali, T.V.; Sujith, A. Asymmetric membranes based on poly(vinyl chloride): Effect of molecular weight of additive and solvent power on the morphology and performance. J. Mater. Sci. 2017, 52, 5708-5725. [CrossRef] 
48. Lagergren, S. About the Theory of so Called Adsorption of Soluble Substances. K. Sven. Vetensk. Handl. 1898, 24, 1-39.

49. Sayed, A.S.; Abdelmottaleb, M.; Cheira, M.F.; Abdel-Aziz, G.; Gomaa, H.; Hassanein, T.F. Date seed as an efficient, eco-friendly, and cost-effective bio-adsorbent for removal of thorium ions from acidic solutions. Aswan Univ. J. Environ. Stud. $2020,1$. [CrossRef]

50. Lin, J.; Wang, L. Comparison between linear and non-linear forms of pseudo-first-order and pseudo-second-order adsorption kinetic models for the removal of methylene blue by activated carbon. Front. Environ. Sci. Eng. China 2009, 3, 320-324. [CrossRef]

51. Mahmoud, N.S.; Atwa, S.T.; Sakr, A.K.; Abdel Geleel, M. Kinetic and thermodynamic study of the adsorption of Ni (II) using Spent Activated clay Mineral. N. Y. Sci. J. 2012, 5, 62-68. [CrossRef]

52. Ho, Y.S.; McKay, G. Pseudo-second order model for sorption processes. Process. Biochem. 1999, 34, 451-465. [CrossRef]

53. Cheira, M.; Awadallah, M.; Rashed, M.; Mohamed, A.E. The use of Alizarin modified bentonite for removal of some heavy metals ions from the wet process phosphoric acid. J. Sci. Res. Sci. 2018, 35, 483-505. [CrossRef]

54. Gado, M.A.; Atia, B.M.; Cheira, M.F.; Elawady, M.E.; Demerdash, M. Highly efficient adsorption of uranyl ions using hydroxamic acid-functionalized graphene oxide. Radiochim. Acta 2021, 109, 743-757. [CrossRef]

55. Juang, R.-S.; Chen, M.-L. Application of the Elovich Equation to the Kinetics of Metal Sorption with Solvent-Impregnated Resins. Ind. Eng. Chem. Res. 1997, 36, 813-820. [CrossRef]

56. Wu, F.-C.; Tseng, R.-L.; Juang, R.-S. Characteristics of Elovich equation used for the analysis of adsorption kinetics in dye-chitosan systems. Chem. Eng. J. 2009, 150, 366-373. [CrossRef]

57. McLintock, I.S. The Elovich Equation in Chemisorption Kinetics. Nature 1967, 216, 1204-1205. [CrossRef]

58. Ding, L.P.; Bhatia, S.K.; Liu, F. Kinetics of adsorption on activated carbon: Application of heterogeneous vacancy solution theory. Chem. Eng. Sci. 2002, 57, 3909-3928. [CrossRef]

59. Langmuir, I. The Adsorption of Gases on Plane Surfaces of Glass, Mica and Platinum. J. Am. Chem. Soc. 1918, 40, 1361-1403. [CrossRef]

60. Gomaa, H.; Cheira, M.F.; Abd-Elmottaleb, M.A.; Saef El-Naser, T.A.; Zidan, I.H. Removal of uranium from acidic solution using activated carbon impregnated with tri butyl phosphate. Biol. Chem. Res. 2016, 126, 313-340.

61. Gomaa, H.; Shenashen, M.A.; Elbaz, A.; Kawada, S.; Seaf El-Nasr, T.A.; Cheira, M.F.; Eid, A.I.; El-Safty, S.A. Inorganic-organic mesoporous hybrid segregators for selective and sensitive extraction of precious elements from urban mining. J. Colloid Interface Sci. 2021, 604, 61-79. [CrossRef]

62. Akar, T.; Kaynak, Z.; Ulusoy, S.; Yuvaci, D.; Ozsari, G.; Akar, S.T. Enhanced biosorption of nickel(II) ions by silica-gel-immobilized waste biomass: Biosorption characteristics in batch and dynamic flow mode. J. Hazard. Mater. 2009, 163, 1134-1141. [CrossRef]

63. Mittal, A.; Kaur, D.; Mittal, J. Batch and bulk removal of a triarylmethane dye, Fast Green FCF, from wastewater by adsorption over waste materials. J. Hazard. Mater. 2009, 163, 568-577. [CrossRef]

64. Heshmati, H.; Torab-Mostaedi, M.; Ghanadzadeh Gilani, H.; Heydari, A. Kinetic, isotherm, and thermodynamic investigations of uranium(VI) adsorption on synthesized ion-exchange chelating resin and prediction with an artificial neural network. Desalin. Water Treat. 2015, 55, 1076-1087. [CrossRef]

65. Hassanin, M.A.; Negm, S.H.; Youssef, M.A.; Sakr, A.K.; Mira, H.I.; Mohammaden, T.F.; Al-Otaibi, J.S.; Hanfi, M.Y.; Sayyed, M.I.; Cheira, M.F. Sustainable Remedy Waste to Generate $\mathrm{SiO}_{2}$ Functionalized on Graphene Oxide for Removal of U(VI) Ions. Sustainability 2022, 14, 2699. [CrossRef]

66. Foo, K.Y.; Hameed, B.H. Insights into the modeling of adsorption isotherm systems. Chem. Eng. J. 2010, 156, 2-10. [CrossRef]

67. Abdel Geleel, M.; Atwa, S.T.; Sakr, A.K. Removal of Cr (III) from aqueous waste using Spent Activated Clay. J. Am. Sci. 2013, 9, 256-262. [CrossRef]

68. Ibrahim, M.E.; Saleh, G.M.; Dawood, N.A.; Aly, G.M. Ocellar lamprophyre dyke bearing mineralization, Wadi Nugrus, eastern desert, Egypt: Geology, mineralogy and geochemical implications. Chin. J. Geochem. 2010, 29, 383-392. [CrossRef]

69. Allam, E.M.; Lashen, T.A.; Abou El-Enein, S.A.; Hassanin, M.A.; Sakr, A.K.; Cheira, M.F.; Almuqrin, A.; Hanfi, M.Y.; Sayyed, M.I. Rare Earth Group Separation after Extraction Using Sodium Diethyldithiocarbamate/Polyvinyl Chloride from Lamprophyre Dykes Leachate. Materials 2022, 15, 1211. [CrossRef]

70. Habashi, F. Extractive metallurgy of rare earths. Can. Metall. Q. 2013, 52, 224-233. [CrossRef]

71. Habashi, F. The recovery of the lanthanides from phosphate rock. J. Chem. Technol. Biotechnol. Chem. Technol. 1985, 35, 5-14. [CrossRef] 